Article

\title{
Characteristics of Refrigerant Boiling Heat Transfer in Rectangular Mini-Channels during Various Flow Orientations
}

\author{
Magdalena Piasecka * (1) and Kinga Strąk \\ Faculty of Mechatronics and Mechanical Engineering, Kielce University of Technology, 25-314 Kielce, Poland; \\ kzietala@tu.kielce.pl \\ * Correspondence: tmpmj@tu.kielce.pl; Tel.: +48-41-342-4320
}

Citation: Piasecka, M.; Strąk, K. Characteristics of Refrigerant Boiling Heat Transfer in Rectangular Mini-Channels during Various Flow Orientations. Energies 2021, 14, 4891. https://doi.org/10.3390/en14164891

Academic Editor: Byoung Jae Kim

Received: 11 July 2021

Accepted: 7 August 2021

Published: 10 August 2021

Publisher's Note: MDPI stays neutral with regard to jurisdictional claims in published maps and institutional affiliations.

Copyright: (c) 2021 by the authors. Licensee MDPI, Basel, Switzerland. This article is an open access article distributed under the terms and conditions of the Creative Commons Attribution (CC BY) license (https:// creativecommons.org/licenses/by/ $4.0 /)$.

\begin{abstract}
This paper reports the results of heat transfer during refrigerant flow in rectangular minichannels at stationary conditions. The impacts of selected parameters on boiling are discussed, i.e., thermal and flow parameters, dimensions and orientation of the channels. Four refrigerants (FC-72, HFE-649, HFE-7000 and HFE-7100) were used as the working fluid. Research was carried out on the experimental set-up with the test section with a single rectangular mini-channel of $180 \mathrm{~mm}$ long and with a group of five parallel mini-channels, each $32 \mathrm{~mm}$ long. The temperature of the mini-channel's heated wall was measured by infrared thermography. Local values of the heat transfer coefficient at the contact surface between the fluid and the plate were calculated using the 1D mathematical method. The results are presented as the relationship between the heat transfer coefficient and the distance along the mini-channel length and boiling curves. Two-phase flow patterns are shown. Moreover, the results concerning various refrigerants and the use of modified heater surfaces are discussed. The main factors influencing the heat transfer process were: mini-channel inclination to the horizontal pane (the highest heat transfer coefficient at $270^{\circ}$ and $0^{\circ}$ ), using modified heater surfaces (especially electroerosion texturing and vibration-assisted laser No. 2 texturing) and working fluids (FC-72 and HFE-7000).
\end{abstract}

Keywords: heat transfer; flow boiling; heat transfer coefficient; refrigerant; mini-channel; modified heater surface; flow orientation

\section{Introduction}

The progressive development of miniaturization and the rapid growth in the areas of technology application have resulted in the need to dissipate increasing amounts of heat from ever smaller surfaces, and therefore it becomes necessary to look for new ways of heat dissipation. One of the effective methods of cooling, enabling the dissipation of high-density heat in a wide temperature range, is boiling heat transfer during flow in mini-channels with the change of the state of aggregation of the working medium. This process is characterized by obtaining high values of the heat transfer coefficient and high heat flux, with a small temperature difference between the heating wall and the saturated liquid. The results of investigations reported in the literature confirm the importance of various factors' influence on boiling heat transfer in mini-channels, such as thermal and flow parameters (temperature and pressure of the fluid, mass flux) and the spatial orientation of mini-channels and their geometry. Modifying the heated wall surfaces of mini-channels could intensify the boiling heat transfer.

In the literature, the influence of various parameters on flow boiling heat transfer has been widely discussed for over a dozen years, however the results relate to different geometries and spatial orientations of the mini-gaps, and various fluids are still investigated.

In Reference [1], an experimental investigation concerning boiling heat transfer during refrigerant flow (R134a, R245fa and R600a) along small-diameter tubes (ranging from 0.38 to $2.6 \mathrm{~mm}$ ) at a wide range of mass and heat fluxes (mass flux from 49 to $2200 \mathrm{~kg} /\left(\mathrm{m}^{2} \cdot \mathrm{s}\right.$ ) 
and heat flux up to $185 \mathrm{~kW} / \mathrm{m}^{2}$ ) were discussed. The effect of the influence of selected experimental parameters, such as geometrical (diameter of a tube) and thermal and flow (mass flux, heat flux, saturation temperature), on the heat transfer coefficient and dry-out vapor quality was examined, for several fluids. It was concluded that the heat transfer coefficient increased with increasing mass flux, heat flux and saturation temperature, while it decreased with increasing tube diameter. The dry-out vapor quality decreased with increasing mass flux and vapor-specific volume. The results and comments were evaluated only for circular mini-channels.

The experimental research in [2] concerned flow boiling heat transfer of refrigerants R134A and R410A flowing along a smooth tube or two surface-enhanced tubes with a $11.5 \mathrm{~mm}$ inside diameter. The experimental tests were conducted with the following parameters: saturation temperatures of 6 and $10{ }^{\circ} \mathrm{C}$, mass flux from 70 to $200 \mathrm{~kg} /\left(\mathrm{m}^{2} \cdot \mathrm{s}\right)$, heat flux from 10 to $35 \mathrm{~kW} / \mathrm{m}^{2}$ and inlet and outlet vapor quality of 0.2 and 0.8 , respectively. The boiling heat transfer coefficient of the enhanced surface tubes was 1.15-1.66 times higher than that of the smooth tubes. Coefficients were evaluated using several widely used correlations. A good predictive ability was obtained when only two correlations were used.

Investigations on flow boiling heat transfer of R32 and R1234yf, pressure drop and flow patterns in a horizontal square mini-channel with a hydraulic diameter of $2 \mathrm{~mm}$ were described in [3]. The authors showed the effects of mass flux, vapor quality, heat flux and refrigerant properties on the flow boiling characteristics. The tested parameters were in the ranges: mass flux: $50-400 \mathrm{~kg} /\left(\mathrm{m}^{2} \cdot \mathrm{s}\right)$, heat flux: $5-40 \mathrm{~kW} / \mathrm{m}^{2}$ and vapor quality: $0.1-0.9$, at a saturation temperature of $15^{\circ} \mathrm{C}$. Detected flow patterns were classified as plug, wavy, churn and annular flows. The data obtained using R32 and R1234yf fluids were analyzed. It was observed that the heat transfer coefficient for R32 achieved higher values in comparison with R1234yf at the same mass flux and vapor quality. Moreover, the frictional pressure drop of R32 was 1.5-2 times higher in comparison to R1234yf at the same mass flux and vapor quality. Additionally, the small effect of channel shape on the frictional pressure drop was observed. The authors also provided a theoretical explanation for these observed relationships.

The aim of the study described in [4] was to investigate the effects of parameters such as mass flux, heat flux, channel diameter and inlet pressure on boiling during FC-72 flow in a semicircular mini-channel. The ranges of the experimental parameters which were tested are as follows: mass flux: $300-2000 \mathrm{~kg} /\left(\mathrm{m}^{2} \cdot \mathrm{s}\right)$, heat flux: $100-300 \mathrm{~kW} / \mathrm{m}^{2}$ and diameter of the channel: $1-5 \mathrm{~mm}$. The results indicated that an increase in the mass flux caused a change in the entropy generation when the flow changed from laminar to transitional flow in small-diameter channels. The increase of the channel diameter resulted in a lower variation in saturated temperature and the reduction of the heat transfer coefficient since the vapor quality achieved high values close to the intermittent dry-out range. The larger channel diameters produced higher entropy generation in comparison to the smaller diameters for each heat flux. During the increase in the inlet pressure, the entropy generation decreased for all tested mass and heat fluxes. Comparative results for fluids with different physical properties than Fluorinert FC-72 would be interesting and allow for the formulation of broader observations and remarks.

In Reference [5], boiling heat transfer during R141b flow in bi-porous mini-channels with dimensions of $1.5 \times 1 \mathrm{~mm}$ was investigated. The heat transfer performance, pressure drop, two-phase flow structures and flow instability at three mass fluxes $(158,253$ and $\left.348 \mathrm{~kg} /\left(\mathrm{m}^{2} \cdot \mathrm{s}\right)\right)$ were discussed. It was noticed that the heat transfer coefficient of biporous mini-channels rose faster with heat flux and was larger than that of the plain surface mini-channel. The pressure drop obtained for the enhanced surface mini-channel increased significantly at high heat flux compared to that of the plain surface mini-channel. Furthermore, it was observed that the flow instability of the bi-porous mini-channel was smaller than that of the plain surface at different mass fluxes. Novel bi-porous minichannels sintered with copper woven tape, which is proposed to enhance the flow boiling 
performance, need more experimental testing. The analysis was based on the experimental research in which only one working fluid, i.e., R141b, was used. This fluid characterizes a low boiling point of $32.1^{\circ} \mathrm{C}$ under normal pressure conditions.

In Reference [6], the experimental investigations of two kinds of model plate heat exchangers, namely a mini-gap exchanger and a mini-channel heat exchanger, were described. A single plate was equipped with a mini-gap of $0.1 \mathrm{~m}$ long and $0.2 \mathrm{~m}$ wide with a thickness of 0.5 and $1.0 \mathrm{~mm}$ or with a set of 50 rectangular mini-channels with a $1 \times 1 \mathrm{~mm}$ cross-section. Ethanol was used as the working fluid. Experiments were conducted in the following conditions: heat flux supplied to the evaporator from 4.1 to $28 \mathrm{~kW} / \mathrm{m}^{2}$ and mass flux from 10 to $92 \mathrm{~kg} /\left(\mathrm{m}^{2} \cdot \mathrm{s}\right)$. Values of the heat transfer coefficient and pressure drop were compared for both heat exchangers as a function of various parameters. It was reported that the coefficient increased with the decreasing thickness of the mini-gap. Furthermore, the coefficient was higher for a mini-channel multiport than for a mini-gap of the same cross-section area. It was indicated that the pressure drop at higher mass flow rate slightly increased for a mini-channel heat exchanger in comparison to a mini-gap heat exchanger. The modified mini-gap surface that was used did not result in a significant heat transfer coefficient increase. The results obtained for such different geometries of heat exchangers with mini-spaces, as presented in this work, in comparative analyses require further study in a wide range of thermal and flow parameters. It should be taken into consideration that the mechanisms of heat transfer processes differ due to the substantial differences in the mini-gap cross-section geometry.

Experimental investigation of water flow boiling heat transfer in a grooved-wall micro-channel was the main aim of Reference [7]. The influence of selected geometrical parameters of the test section was investigated, including the silicon base channel aspect ratios $(1,2.5$ and 4), groove spacing ratios $(2,5$ and 8$)$ and groove depths $(15,30$ and $45 \mu \mathrm{m})$ on the flow boiling. During the tests, flow patterns in the micro-channels were observed by using a high-speed camera. Experiments were conducted for mass flux of $446-963 \mathrm{~kg} /\left(\mathrm{m}^{2} \cdot \mathrm{s}\right)$ and heat flux of $36.3-502.8 \mathrm{~kW} / \mathrm{m}^{2}$. It was observed that the best improvement of heat transfer was achieved using the aspect ratio of 2.5 in the grooved-wall channel. The heat transfer coefficient value firstly increased as the aspect ratio increased from 1 to 2.5, and then decreased when the aspect ratio increased from 2.5 to 4 . Research was limited to testing one modified developed surface (a grooved wall). Using other developed wall surfaces could significantly affect the results. As the tested micro-channel heat sink was fabricated by the standard silicon MEMS fabrication technique, the geometry variation could be over a wide range.

In Reference [8], the study of an experimental research on the water flow boiling heat transfer in a mini-channel with a $2.12 \mathrm{~mm}$ inner diameter, vertically oriented with the upward flow, was presented. The experimental parameters tested were the mass flux from 20 to $120 \mathrm{~kg} /\left(\mathrm{m}^{2} \cdot \mathrm{s}\right)$ and the average vapor quality in the test section inlet of 0.05 to 0.9 . The two-phase flow patterns were observed at the test section and classified as three patterns: slug, annular and churn flows. The characteristics of the heat transfer and fluid flow were analyzed. It was observed that the highest mass flux yielded the highest convective heat transfer coefficient. Moreover, the pressure loss was higher at a higher mass flux. Only one channel geometry was applied in the experiments. Experimental research focused on using water as the working fluid. Using other coolers is needed to compare the results. Moreover, setting the downward flow or other spatial orientation of the test section will significantly influence the data obtained from experiments, especially forming two-phase structures.

The main aim of Reference [9] was boiling heat transfer during deionized water flow in a single mini-channel of $1.8 \mathrm{~mm}$ width and $0.9 \mathrm{~mm}$ height. The following experimental parameters were set during the tests: the wall heat flux in the range of $204.7-431.3 \mathrm{~kW} / \mathrm{m}^{2}$ and mass fluxes $\left(20,40\right.$ and $\left.60 \mathrm{~kg} /\left(\mathrm{m}^{2} \cdot \mathrm{s}\right)\right)$. It was noticed that the heat transfer coefficient showed an irregular trend with increasing heat flux or vapor quality, while it increased with increasing mass flux. Furthermore, the pressure drop increased with an increase in heat flux or in exit vapor quality. During the experiments, the bubbly, slug and annular 
flow patterns were recorded. Experiments were conducted only for low mass fluxes. The authors did not compare their own research results with refrigerants and other geometries of the mini-channel.

The study of flow boiling of water and n-pentane/water and freon-11/water emulsion of heat transfer in a mini-channel was presented in Reference [10]. In the test section, a mini-channel of $1.1 \mathrm{~mm}$ hydraulic diameter, horizontally oriented, was produced. The mean heat transfer coefficient from the channel wall to emulsion was higher than to water at bubble and slug flow conditions of a two-phase flow. The variations in the liquid temperature at the channel inlet and outlet and the excess pressure in the system during the instability of two-phase flow were examined. The experiments were conducted at mass fluxes of 42 and $75 \mathrm{~kg} /\left(\mathrm{m}^{2} \cdot \mathrm{s}\right)$, and with an increase in the mass flow, the segment where water boiling begins additionally shifts closer to the channel outlet. The presence of an additional vapor phase in a mini-channel, which consists of the vapor of a low-boiling liquid, contributes to the appearance of instability and boiling crisis at lower heat flux, as compared with pure water. The intensification of boiling heat transfer in a mini-channel was observed in experiments in which emulsions were used in comparison to pure water. The temperature of a two-phase flow at the outlet during the boiling of an emulsion proved to be higher than the boiling temperature of a dispersed phase. The study does not take into account the influence of the spatial orientation of the mini-channel on forming two-phase flow structures. The influence of the variable geometry of the channel on heat transfer could also be investigated.

Pool boiling heat transfer was the subject of numerous publications. Examples of articles presenting the results of such a topic can be found in References [11-16]. Research on distilled water and ethyl alcohol pool boiling on copper micro-channels modified by a laser beam was described in [11] and wire mesh coatings made of copper and phosphor bronze in [12]. It was detected that the laser texturing provided a significant improvement in pool boiling heat transfer and enabled the production of highly efficient phase-change heat exchangers [11]. Moreover, it was shown that the metal meshes sintered onto the heater surfaces can be very effective in providing enhancement of boiling heat transfer [12].

The authors of Reference [13] studied pool boiling heat transfer of water at subatmospheric pressure and low saturation temperature. The experiments were conducted for three vapor pressures $(2.4,3.1$ and $4.1 \mathrm{kPa})$, four levels of liquid and five applied heat fluxes (in the range 3.6-7.1 $\mathrm{kW} / \mathrm{m}^{2}$ ). The following boiling regimes were identified: convection or small popping bubbles, isolated bubbles, intermittent boiling and fully developed boiling. For the high level of liquid, mostly convection or small popping bubbles were shown.

Experimental results relating to pool boiling heat transfer on open micro-channel surfaces with dimensions from 0.2 to $0.4 \mathrm{~mm}$ wide and from 0.2 to $0.5 \mathrm{~mm}$ deep [14,16], and on plain micro-fins and micro-fins with a porous layer of $1.0 \mathrm{~mm}$ high [15], were discussed. The boiling heat transfer coefficients achieved from the surface open micro-channel surfaces were 3 times higher [14] or 2.5-4.9 times higher [16] compared to the smooth surface. The plain micro-fin surfaces helped to obtain an increase in the heat transfer coefficient of two times that of the micro-fins with perforated foil [15].

Using processes of heat transfer with the change of phase, which occur both during boiling and in the reverse process, i.e., condensation, are an effective way of cooling. In the literature, investigations of heat transfer during condensation in small channels are widely discussed [17,18].

At Kielce University of Technology, previous investigations on boiling heat transfer during cooling liquids' flow [19-21] along rectangular mini-channels of changeable spatial orientation, with smooth or modified heater surfaces, were discussed in $[20,22,23]$. The thermoelasticity problem was the main topic of References [24,25] dealing with a two-layer plate [24] and non-contacting face seals [25].

This work provides a summary of the results collected during experimental work in a laboratory setup, in which an essential element was a model mini-channel heat exchanger 
with a singular long mini-channel or a set of short parallel mini-channels. It aims to deliver a summary of observations and comments concerning boiling heat transfer during refrigerant flow in rectangular mini-channels of different dimensions (depth, length and width), with changeable inclination to the horizontal plane and asymmetrically heatedwith a smooth heated wall or a modified one. A wide range of experimental tests and a large number of cooling fluids used in the study are additional advantages of this work and a novelty in experimental investigation. Up to now, preliminary research has been performed on the 3 and 5 mini-channel test sections [26,27]. Previous studies were carried out using a singular mini-channel, which are summarized here, with many additional parameters of the experiment being tested.

\section{The Experimental Rig and Methodology}

\subsection{Main Circuits}

The main systems of the experimental setup are illustrated in Figure 1. It consists of: a FC-72 circulating loop including the test section with a singular mini-channel or five parallel mini-channels, the current supply and control system with the heat source and the data and image acquisition system comprising the lighting system. Infrared cameras (FLIR, model E60 or A655SC, USA) were used to determine changes in temperature on the outer surface of the mini-channel's heated wall. Two-phase flow patterns were observed through the mini-channel's glass wall using a high-speed camera (JAI, model SP-50 0 0M-CXP2, Denmark/Japan) and illuminated by high-power LEDs.

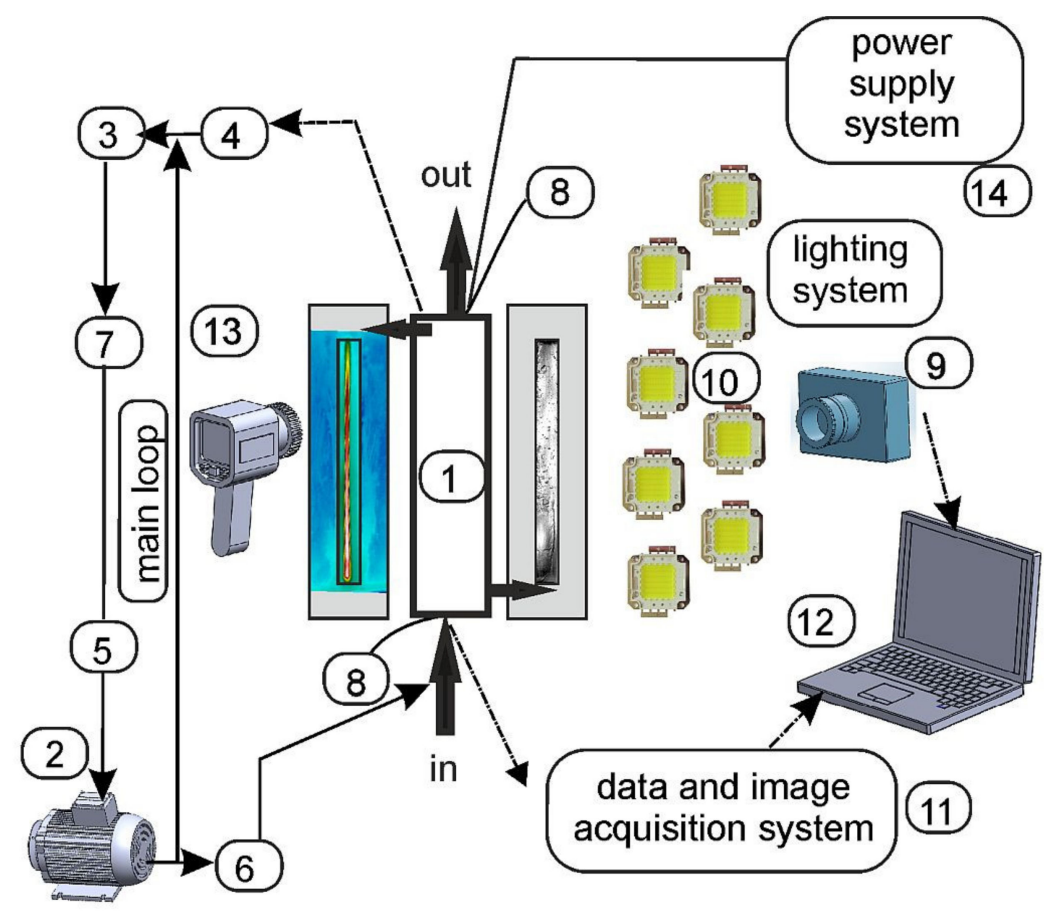

Figure 1. The main systems of the experimental setup: 1-test section, 2-gear pump, 3- compensating tank/pressure regulator, 4-tube-type heat exchanger, 5-filter, 6-mass flow meter, 7-deaerator, 8-pressure sensor, 9-high-speed camera, 10-LEDs (400 W), 11-data acquisition station, 12-PC, 13-infrared camera, 14-power supply system.

The mass flow rate was measured due to the Coriolis mass flow meter (Endress+Hauser, model Proline Promass A 100, Switzerland). The pressure of the fluid at the inlet and outlet of the mini-channels was measured by pressure sensors (Endress+Hauser, model PMP71, Cerabar S, Switzerland). 
The test section was set at four inclination angles in relation to the horizontal plane $\left(0^{\circ}, 90^{\circ}, 180^{\circ}\right.$ and $\left.270^{\circ}\right)$. Four refrigerants (FC-72, HFE-649, HFE-7000 and HFE-7100) were used as the working fluid flowing along mini-channels, and asymmetrically heated.

\subsection{Test Sections}

Two constructions of the test section were applied during experiments: the first one with a singular mini-channel of $1.7 \mathrm{~mm}$ depth and $180 \mathrm{~mm}$ length (named as "the 1st") and the second with five parallel mini-channels of $1 \mathrm{~mm}$ depth and $32 \mathrm{~mm}$ length (named as "the 2nd"). Geometrical characteristics of the test sections are specified in Table 1, while their views and the longitudinal section are shown in Figure 2.

Table 1. Geometrical characteristics of mini-channels in the two test sections.

\begin{tabular}{ccc}
\hline \multirow{2}{*}{ Geometrical Characteristics of Mini-Channels } & \multicolumn{2}{c}{ Test Section } \\
\cline { 2 - 3 } & the 1st & the 2nd \\
\hline Number of mini-channels & 1 & 5 \\
Length of a mini-channel, mm & 180 & 32 \\
Width of a mini-channel, mm & 16 & 6 \\
Depth of a mini-channel, mm & 1.7 & 1 \\
\hline
\end{tabular}

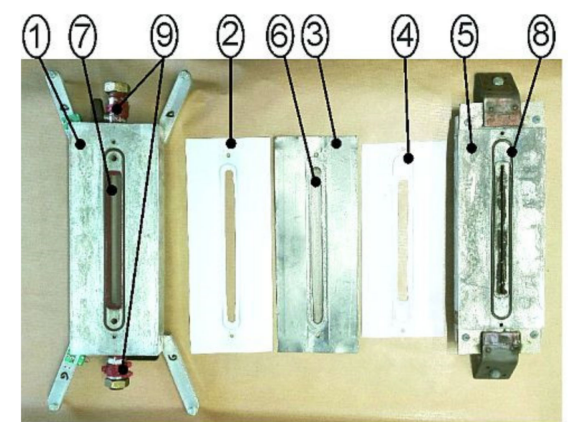

(a)

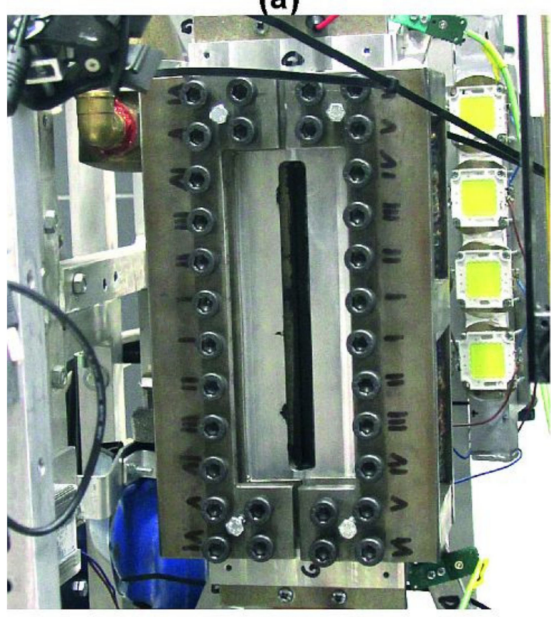

(c)

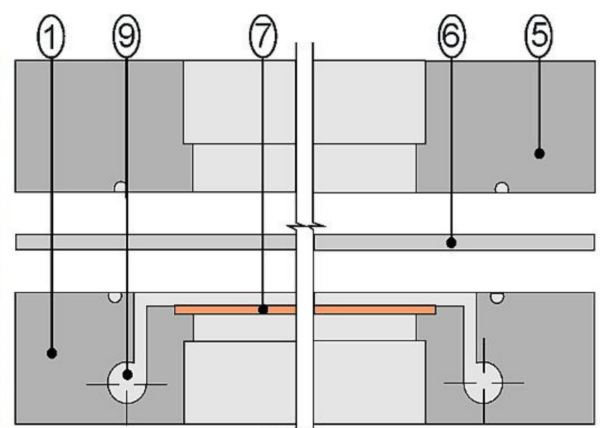

(b)

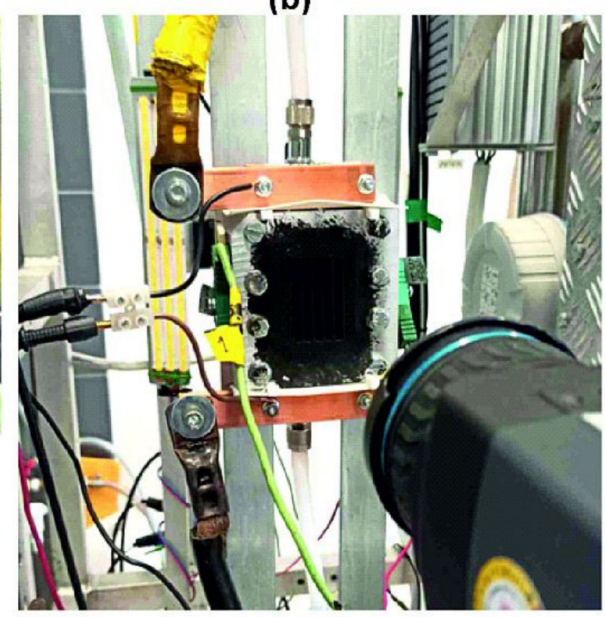

(d)

Figure 2. General characteristics of test sections: (a) view of the 1st test section components, (b) longitudinal section; (c) view of the 1st test section; (d) view of the 2nd test section; 1 -channel body, 2, 4-Teflon plates, 3-graphite plate, 5-front cover, 6-heated plate, 7-glass panel, 8-O-ring, 9 -temperature and pressure sensors.

Figure 2a presents a view of the 1st test section components (the 2nd test section is similarly constructed). The mini-channel is positioned between the glass plate (7) and the heated plate (6), which is made of Haynes-230 alloy. The channel's side walls are formed by Teflon plates (2). At the inlet and outlet of the test section, a K-type thermocouple and 
pressure sensors are mounted (9). A silicone O-ring (8) is placed in the groove to avoid the leakage of the fluid, whereas a graphite plate (3) is applied for electrical insulation between the heated plate and other metal elements of the test section. In Figure $2 b$, a longitudinal view of the test section is presented. In Figure $2 c, d$, the views of the test sections from the side of the heated plate are shown, of the 1st test section (Figure 2c) and of the 2nd one (Figure 2d).

\subsection{Experimental Parameters and Accuracies}

The main features of the experiments are specified in Table 2, including: basic experimental parameters, spatial positions of the test section, working fluids and heated plate specification. Boiling regions are also listed.

Table 2. Main features of the experiments.

\begin{tabular}{|c|c|}
\hline Features of Experiments & Specific Data \\
\hline Mass flux, $G$ & $89 \div 616\left(\mathrm{~kg} /\left(\mathrm{m}^{2} \cdot \mathrm{s}\right)\right)$ \\
\hline Inlet pressure, $p_{\text {in }}$ & $110 \div 370(\mathrm{kPa})$ \\
\hline Inlet liquid subcooling & $35 \div 58(\mathrm{~K})$ \\
\hline Heat flux (density), $q_{w}$ & $2.5 \div 102\left(\mathrm{~kW} / \mathrm{m}^{2}\right)$ \\
\hline Spatial orientation of the test section & $0^{\circ}, 90^{\circ}, 180^{\circ}, 270^{\circ}$ \\
\hline Refrigerant & $\begin{array}{l}\text { FC-72, HFE-649, HFE-7000, HFE-7100 } \\
\text { vibration-assisted laser surface texturing (Nos. } \\
1,2 \text { and 3) }\end{array}$ \\
\hline Modified heated wall surface produced by: & $\begin{array}{l}\text { - } \quad \text { electroerosion surface texturing } \\
\text { - } \quad \text { sintering iron powder to the plate base } \\
\text { soldering iron powder to the plate base }\end{array}$ \\
\hline Boiling region & subcooled/saturated \\
\hline
\end{tabular}

Absolute errors of the main experimental parameters, estimated on the basis of the data of manufacturers of measurement devices, are provided in Table 3. The details of the conducted error analysis can be found in [21].

Table 3. Absolute errors of the main experimental parameters.

\begin{tabular}{|c|c|c|}
\hline Experimental Parameter & Absolute Error & More Specific Data \\
\hline \multirow{4}{*}{$\begin{array}{c}\text { Mass flow rate } \\
\text { Absolute Pressure } \\
\text { Temperature of the heated plate, } T_{p} \\
\text { Temperature of the fluid, } T_{f} \text {, at the } \\
\text { inlet/outlet }\end{array}$} & $1.67 \times \cdot 10^{-5}(\mathrm{~kg} / \mathrm{s})$ & maximum error of reading \\
\hline & $1285(\mathrm{~Pa})$ & absolute error of the measurement \\
\hline & $1(\mathrm{~K})$ & absolute error of the measurement (IRT) \\
\hline & $0.34(\mathrm{~K})$ & absolute error of the measurement [21] \\
\hline
\end{tabular}

The temperature of the fluid at the inlet and outlet of the mini-channel was measured due to K-type thermocouples manufactured by Czaki Thermo-Product (Poland). Thermocouples were connected via a thermocouple module (DBK84) to the data acquisition station (DaqLab/2005). Such temperature measurement system has been used in the laboratory for many years. All thermocouples were additionally calibrated by using a calibrator of thermocouple type 9102 HDRC, manufactured by Hart Scientific (USA). The calibrating procedure, the detailed information concerning the temperature measurement system with K-type thermocouples and the absolute error of temperature measurement were described in [28].

The basic physical properties of the refrigerants under experimental investigation, i.e., FC-72, HFE-649, HFE-7000 and HFE-7100 (3M), are shown in Table 4. 
Table 4. Basic physical properties of refrigerants under experimental investigation.

\begin{tabular}{cccccc}
\hline Refrigerant & $\begin{array}{c}\text { Boiling Point Temperature } \\
(\mathbf{K})\end{array}$ & $\begin{array}{c}\text { Density } \\
\mathbf{( k g / \mathbf { m } ^ { 3 } )}\end{array}$ & $\begin{array}{c}\text { Kinematic Viscosity } \\
\left(\mathbf{m}^{\mathbf{2} / \mathbf{s})}\right.\end{array}$ & $\begin{array}{c}\text { Vapor Pressure } \\
\mathbf{( P a )}\end{array}$ & $\begin{array}{c}\text { Heat of Evaporation } \\
\mathbf{( J / k g})\end{array}$ \\
\hline FC-72 & 329 & 1680 & $0.38 \times \cdot 10^{-6}$ & $30 \cdot 10^{3}$ & $88 \times \cdot 10^{3}$ \\
HFE-649 & 322 & 1600 & $0.40 \times \cdot 10^{-6}$ & $40 \cdot 10^{3}$ & $88 \times \cdot 10^{3}$ \\
HFE-7000 & 307 & 1400 & $0.32 \times \cdot 10^{-6}$ & $65 \cdot 10^{3}$ & $142 \times \cdot 10^{3}$ \\
HFE-7100 & 334 & 1510 & $0.38 \times \cdot 10^{-6}$ & $27 \cdot 10^{3}$ & $112 \times \cdot 10^{3}$ \\
\hline
\end{tabular}

The heated plates were made of Haynes-230 alloy or Hastelloy X alloy, and were 0.45 or $0.65 \mathrm{~mm}$ thick. The arithmetic mean deviations of the roughness profile of the smooth plate surface are as follows: $R a=0.175 \mu \mathrm{m}$ (Haynes-230) and $R a=0.133 \mu \mathrm{m}$ (Hastelloy X). Modified surfaces of the heated plates were investigated in terms of intensification of heat transfer. Views of the investigated modified heated plate surfaces are revealed in Figure 3. Several types of modified surfaces were tested, as follows: vibration-assisted laser surface texturing (three textures dependent on the applied parameters of the production process, named as No. 1, No. 2 and No. 3), electroerosion surface texturing and sintering or soldering iron powder to the alloy plate base (porous surfaces).

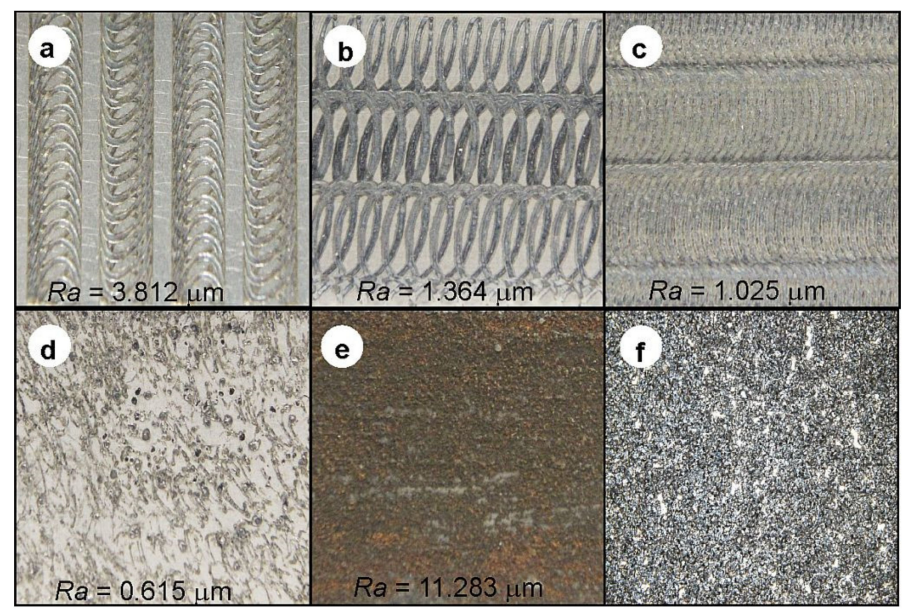

Figure 3. View of modified heated plate surfaces produced by: $(\mathbf{a}-\mathbf{c})$ vibration-assisted laser texturing, No. 1 (a), No. 2 (b), No. 3 (c); (d) electroerosion texturing, and (e,f) porous metal surfaces produced by soldering (e) and (f) sintering iron powder to the alloy base. $R a$-arithmetic mean deviation of the roughness profile of the plate surface.

During experiments, the test section was set at various inclinations to the horizontal plane. Four spatial orientations of the test section were tested: $0^{\circ}, 90^{\circ}, 180^{\circ}$ and $270^{\circ}$. Figure 4 illustrates the positioning of the heated wall and the mini-channel in the test section. The flow direction in each case is also indicated.

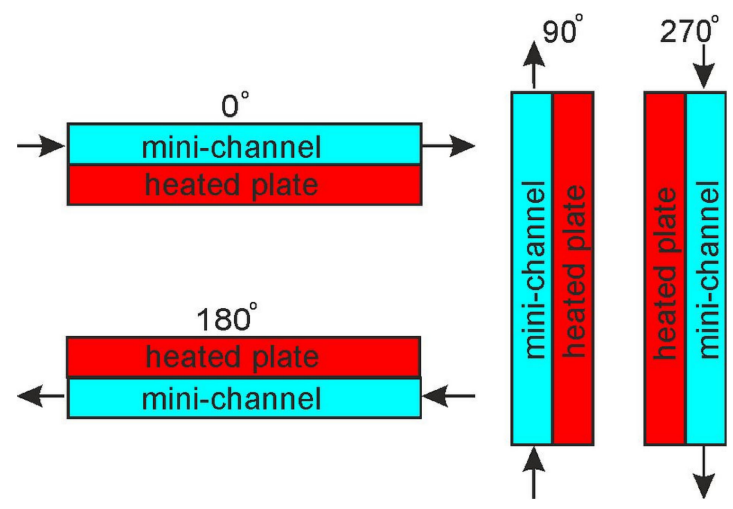

Figure 4. Spatial orientations of the test section. 


\section{HTC Determination}

Heat transfer coefficient (HTC) was determined from the 1D approach of heat flow across the test section layers. In this simple mathematical approach, only one direction of heat flow was assumed, i.e., perpendicular to the fluid flow direction and the minichannel width. The 2D approach using Trefftz functions for solving the inverse problem and the commercial software ADINA were also applied in the computations. The results were discussed in the authors' previous works [19,21,26,27,29]. It allowed to verify the correctness of the 1D approach. According to the results obtained from the 1D and 2D approaches at the saturated boiling region presented in [30], it was concluded that the distribution of HTC values was similar for both methods at the same heat flux.

Local HTCs $(H T C(x))$ were calculated from the following dependence [20]:

$$
H T C(x)=q_{w} /\left(T_{P}\left(x, \delta_{P}\right)-T_{f}(x)-q_{w} \cdot \frac{\delta_{P}}{\lambda_{P}}\right)
$$

where:

$x$-direction perpendicular to the fluid flow direction and the mini-channel width,

$T_{P}(x)$-local temperature of the heated plate outer surface measured by infrared thermography,

$T_{f}(x)$-local fluid temperature based on the assumption of the linear distribution from the channel inlet to the outlet: (i) of the liquid bulk temperature $\left(T_{l}\right)$ at the subcooled boiling region, and (ii) of the liquid saturated temperature $\left(T_{\text {sat }}\right)$ at the saturated boiling region, both based on experimental measurements (of fluid temperature or pressure at the inlet and outlet, respectively),

$\lambda_{P}$-thermal conductivity of the heated plate,

$\delta_{P}$-thickness of the heated plate,

$q_{w}$-heat flux transferred from the heated plate to the fluid, defined as:

$$
q_{w}=(I \cdot \Delta U) / A
$$

where:

I-current supplied to the heated plate,

$\Delta U$-voltage drop across the heated plate,

$A$-area of the heated plate.

The total heat flux transferred from the heated plate to the fluid was reduced by heat loss to the ambient air from the heated plate (calculated similarly as in [22]).

It is assumed that the average uncertainties of the HTC and $q_{w}$ achieve similar values, as determined in previous experiments conducted by the authors, discussed in works such as References [21,22]. Average uncertainties were calculated in accordance with the principles of measurement accuracy analysis. The uncertainties of HTC were in the range $11.0-19.8 \%$ at the subcooled boiling region [22]. At the saturated boiling region, the errors of the HTC were noticeably higher, from $14.2 \%$ to $47.9 \%$ [21]. The average uncertainties of $q_{w}$ for both boiling regions were in the range from $5.5 \%$ to $10.5 \%$ [22]. When analyzing the tested experiments, the highest value of the uncertainty of $q_{w}$ equals $4.7 \%$ at the lowest heat flux.

\section{Results and Discussion}

\subsection{Database of Selected Experiments}

The database of experiments due to the study of the influence of the parameter/factor on flow boiling was large. To clearly compile the data adopted for analysis from a wide experimental database source according to the basic criteria of their selection, Table 5 illustrates their summary. In the second column of this table, the criterion of the analysis is provided, referring to the number of figures illustrating the selected results from experiments. In other columns, more detailed information concerning the geometrical 
parameters of the test section, working fluid and thermal-flow parameters are shown with specifications of the boiling region.

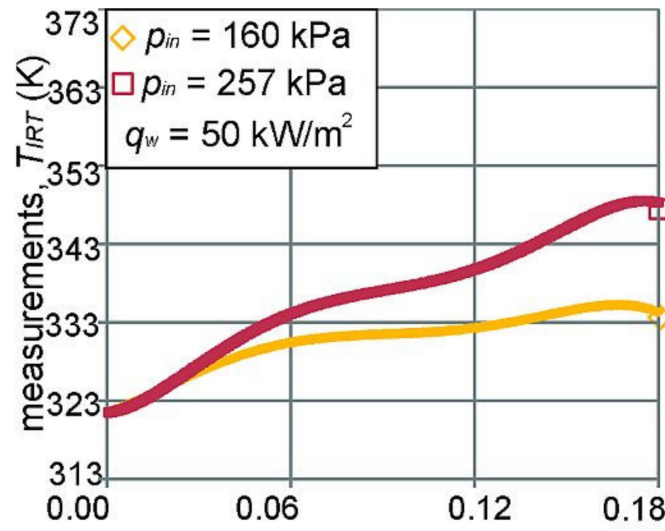

distance from the mini-channel inlet, $x(\mathrm{~m})$

(a)

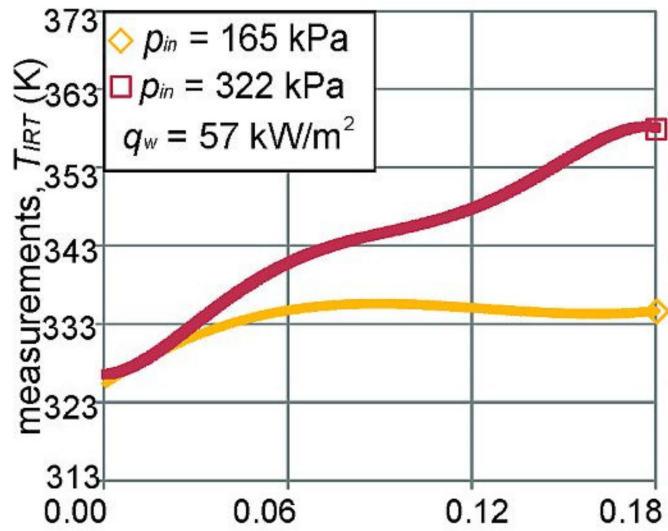

distance from the mini-channel inlet, $x(\mathrm{~m})$

(c)

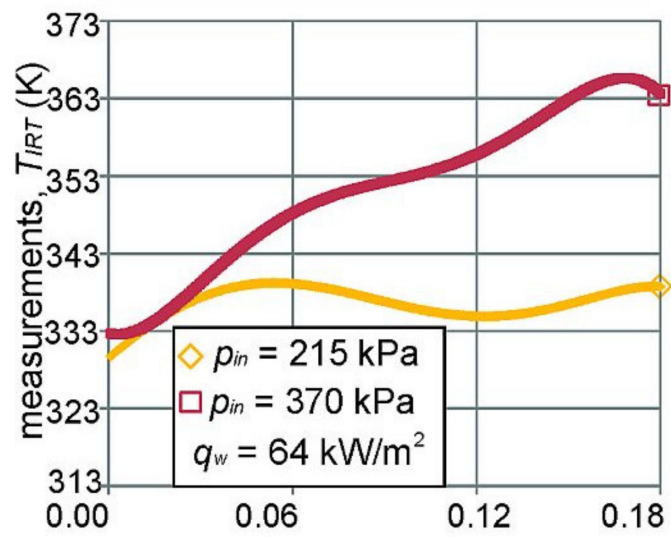

distance from the mini-channel inlet, $x(\mathrm{~m})$

(e)

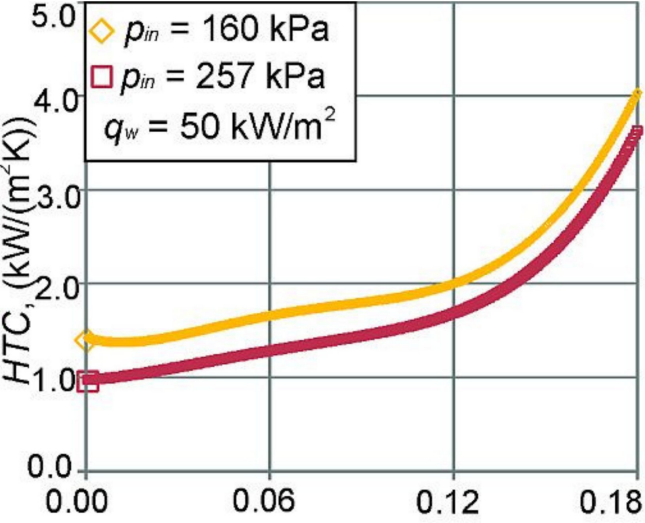

distance from the mini-channel inlet, $x(\mathrm{~m})$

(b)

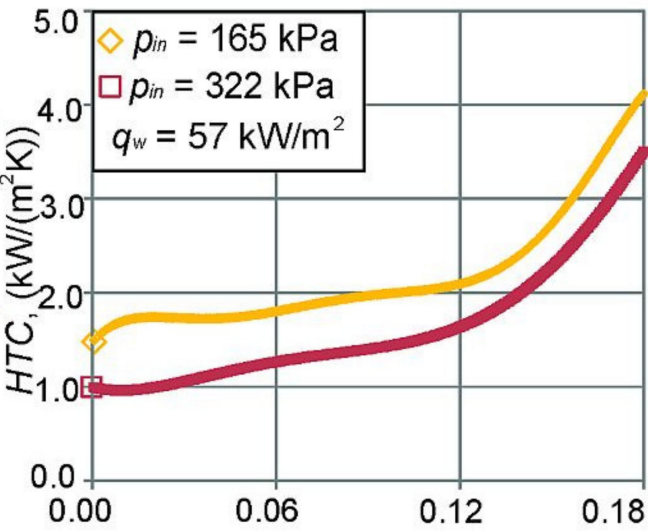

distance from the mini-channel inlet, $x(\mathrm{~m})$

(d)

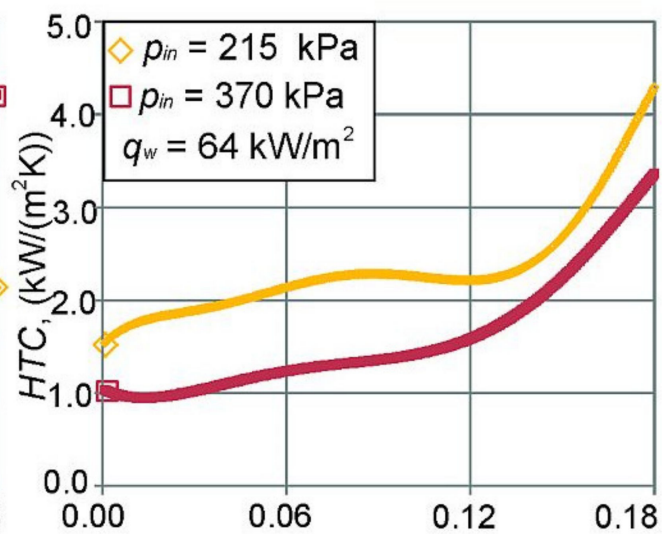

distance from the mini-channel inlet, $x(\mathrm{~m})$

(f)

Figure 5. Plate temperature measurements using the IR camera $(\mathbf{a}, \mathbf{c}, \mathbf{e})$ and heat transfer coefficient $(\mathbf{b}, \mathbf{d}, \mathbf{f})$, both vs. distance from the mini-channel inlet; subcooled boiling region; various inlet pressures; vertical channel orientation $\left(90^{\circ}\right)$; mass flux of $400 \mathrm{~kg} /\left(\mathrm{m}^{2} \mathrm{~s}\right)$; modified heated plate surface (vibration-assisted laser surface texturing No. 2); HFE-649; $L_{I R T}=180 \mathrm{~mm}$. 
Table 5. The database of research on the influence of selected factors on flow boiling in mini-channels.

\begin{tabular}{|c|c|c|c|c|c|c|c|c|c|}
\hline No. & $\begin{array}{l}\text { Tested Factor } \\
\text { (Figure) }\end{array}$ & Boiling Region & $\begin{array}{l}\text { Channel Length, } L_{I R T} \text {, } \\
\text { Heated Plate Surface, } S\end{array}$ & Fluid, $f$ & $\begin{array}{c}\text { Spatial Orientation } \\
\text { of Mini-Channels, } O\end{array}$ & $\begin{array}{l}\text { Heat Flux, } q_{w} \\
\quad\left(\mathbf{k W} / \mathbf{m}^{2}\right)\end{array}$ & $\begin{array}{c}\text { Mass Flux, } G \\
\left(\mathrm{~kg} /\left(\mathrm{m}^{2} \mathrm{~s}\right)\right)\end{array}$ & $\begin{array}{c}\text { Inlet Pressure, } p_{\text {in }} \\
(\mathrm{kPa})\end{array}$ & $\begin{array}{c}\text { Inlet Liquid } \\
\text { Subcooling (K) }\end{array}$ \\
\hline$\# 1$ & $\begin{array}{l}\text { Inlet pressure } \\
\quad \text { (Figure 5) }\end{array}$ & subcooled & $180 \mathrm{~mm}$, v.a. las. 2 & HFE-649 & $90^{\circ}$ & $\begin{array}{l}50 \\
57 \\
67\end{array}$ & 400 & $\begin{array}{l}160,257 \\
165,322 \\
215,370\end{array}$ & 53 \\
\hline \#2 & $\begin{array}{l}\text { Mass flux } \\
\text { (Figure 6) }\end{array}$ & subcooled & $180 \mathrm{~mm}$, smooth & FC-72 & $90^{\circ}$ & $48,62,78$ & $209,414,616$ & 160 & 58 \\
\hline \#3 & $\begin{array}{c}\text { Mass flux, } \\
\text { channel orientation } \\
\text { (Figure 7) }\end{array}$ & subcooled & $180 \mathrm{~mm}$, smooth & HFE-649 & $90^{\circ}, 270^{\circ}$ & $42,56,72$ & $209,414,616$ & 170 & 48 \\
\hline$\# 4$ & $\begin{array}{l}\text { Mass flux } \\
\text { (Figure 8) }\end{array}$ & subcooled & $32 \mathrm{~mm}$, smooth & FC-72 & $90^{\circ}$ & $2.5,9.8,21.3$ & 89,368 & 111 & 38 \\
\hline \#5 & $\begin{array}{l}\text { Channel orientation } \\
\text { (Figure 9) }\end{array}$ & subcooled & $32 \mathrm{~mm}$, smooth & FC-72 & $\begin{array}{c}0^{\circ} \\
90^{\circ} \\
180^{\circ}\end{array}$ & $2.5,9.8,21.3$ & 440 & 110 & 35 \\
\hline \#6 & $\begin{array}{l}\text { Working fluid } \\
\text { (Figure 10a,b) }\end{array}$ & subcooled & $180 \mathrm{~mm}$, v.a. las. 2 & $\begin{array}{c}\text { FC-72 } \\
\text { HFE-649 } \\
\text { HFE-7000 } \\
\text { HFE-7100 }\end{array}$ & $90^{\circ}$ & 55,81 & 423 & 170 & 39 \\
\hline$\# 8$ & $\begin{array}{l}\text { Heated plate surface } \\
\quad \text { (Figure 11a,b) }\end{array}$ & subcooled & $180 \mathrm{~mm}$, v.a. las. 2 & FC-72 & $90^{\circ}$ & 47,73 & 356 & 121 & 42 \\
\hline \#9 & $\begin{array}{l}\text { Heated plate surface } \\
\quad \text { (Figure } 11 \mathrm{c}, \mathrm{d})\end{array}$ & saturated & $\begin{array}{l}180 \mathrm{~mm} \text {, smooth, v.a. las. } \\
\text { 1,2,3, electr., sold. and } \\
\text { sin. i.p. }\end{array}$ & FC-72 & $90^{\circ}$ & 84,93 & 349 & 140 & 43 \\
\hline
\end{tabular}

v.a. las.--vibration-assisted laser surface texturing, electr.-electroerosion texturing (spark erosion), sold/sin. i.p.--porous metal surfaces produced by soldering and sintering iron powder. 


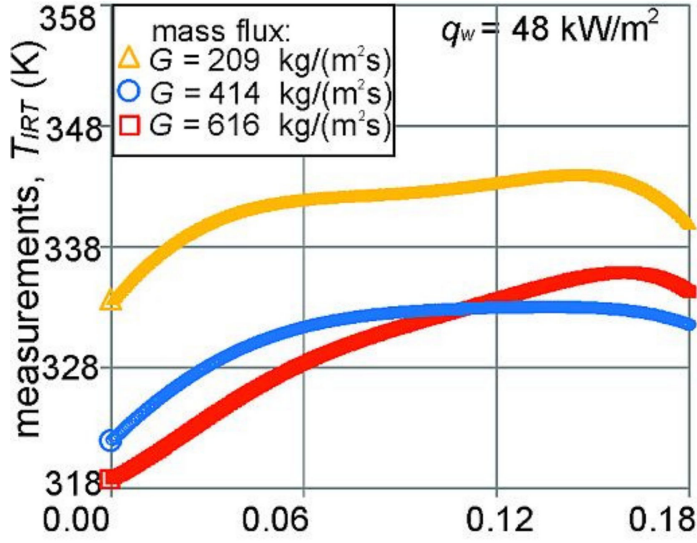

distance from the mini-channel inlet, $x(\mathrm{~m})$

(a)

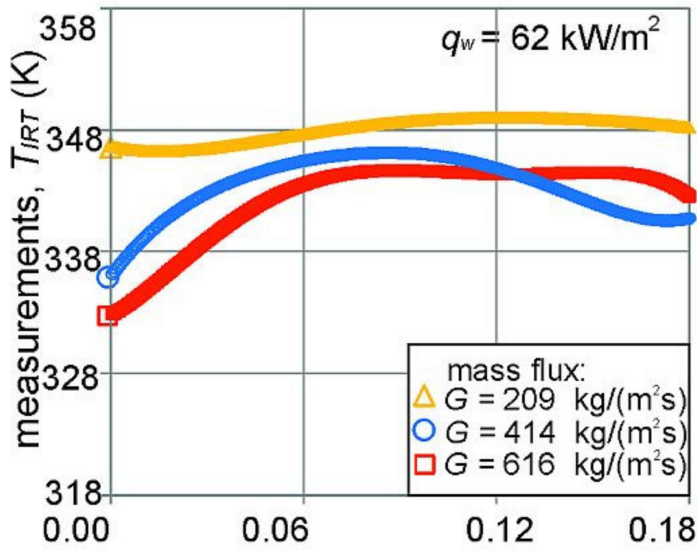

distance from the mini-channel inlet, $x(\mathrm{~m})$

(c)

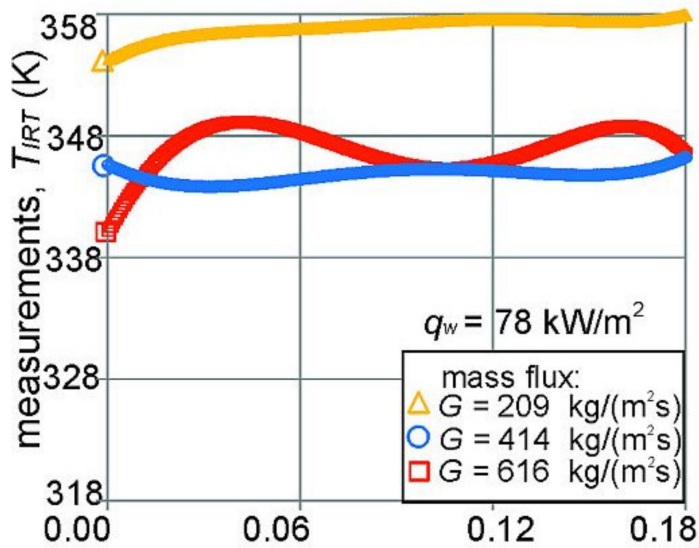

distance from the mini-channel inlet, $x(\mathrm{~m})$

(e)

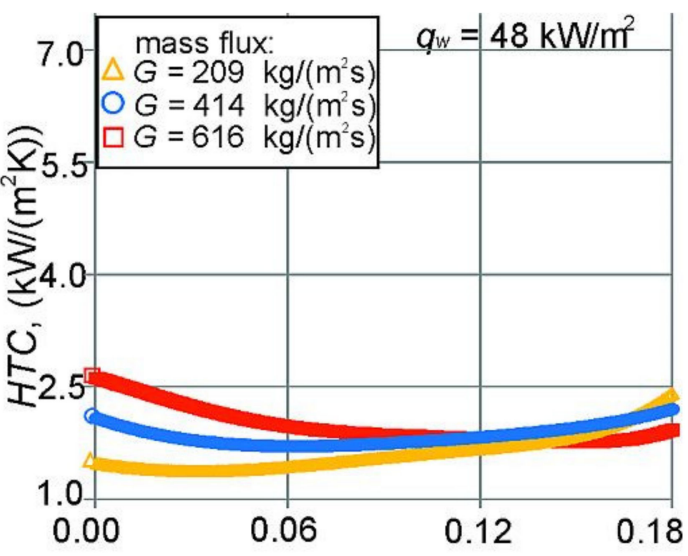

distance from the mini-channel inlet, $x(\mathrm{~m})$

(b)

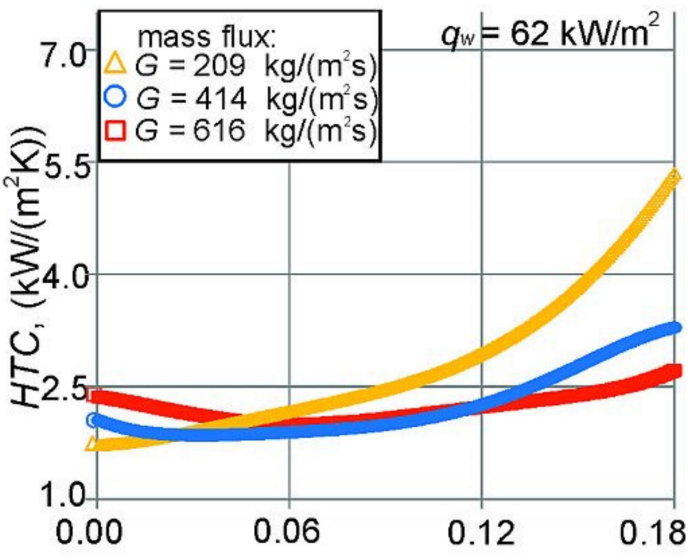

distance from the mini-channel inlet, $x(\mathrm{~m})$

(d)

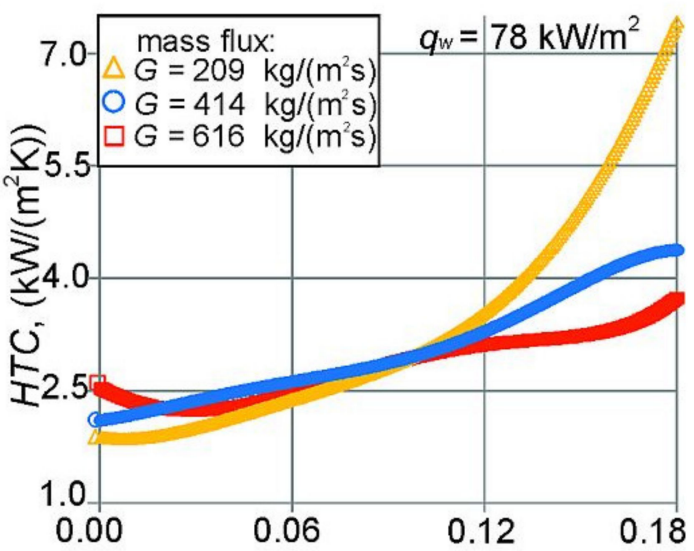

distance from the mini-channel inlet, $x(\mathrm{~m})$

(f)

Figure 6. Plate temperature measurements using the IR camera $(\mathbf{a}, \mathbf{c}, \mathbf{e})$ and heat transfer coefficient $(\mathbf{b}, \mathbf{d}, \mathbf{f})$, both vs. distance from the mini-channel inlet; subcooled boiling region; various mass fluxes; vertical channel orientation $\left(90^{\circ}\right)$; smooth heated plate; FC-72; $L_{I R T}=180 \mathrm{~mm}$. 


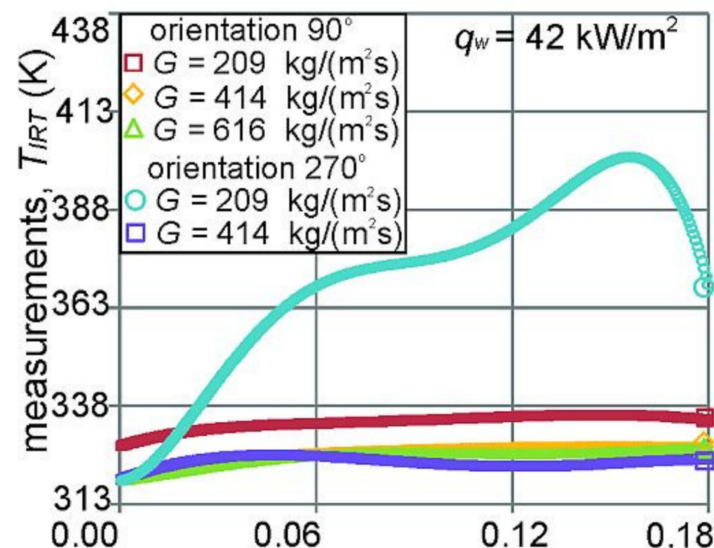

distance from the mini-channel inlet, $x(\mathrm{~m})$

(a)

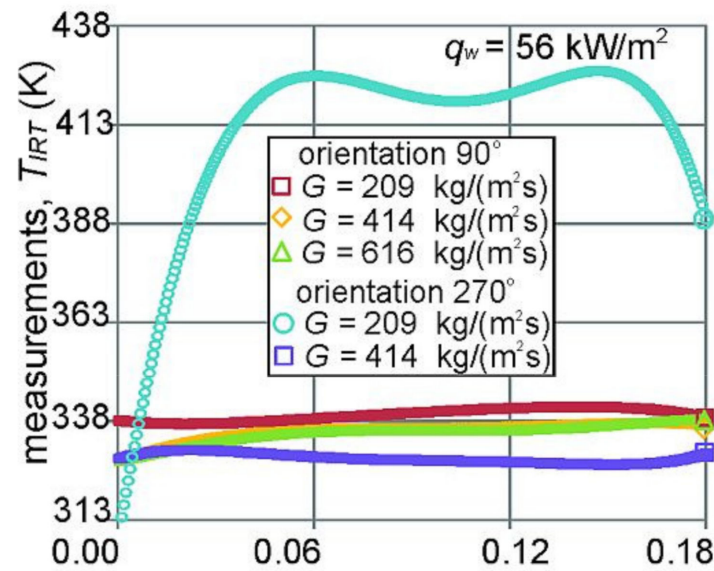

distance from the mini-channel inlet, $x(\mathrm{~m})$

(c)

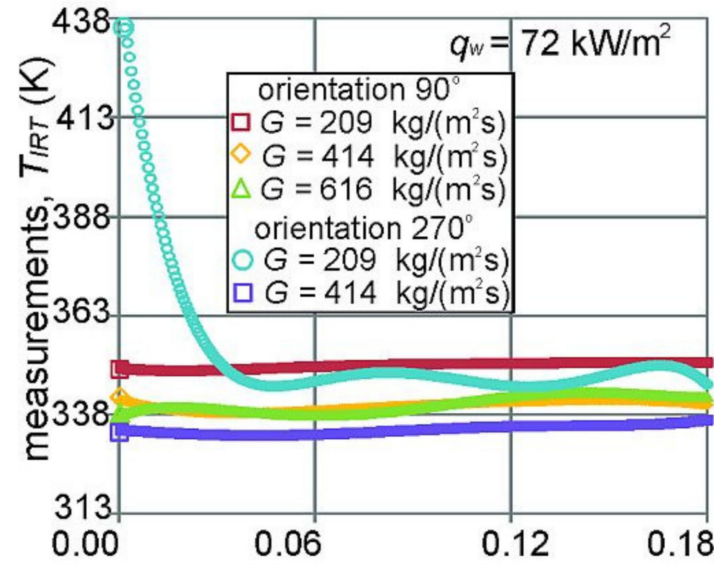

distance from the mini-channel inlet, $x(\mathrm{~m})$

(e)

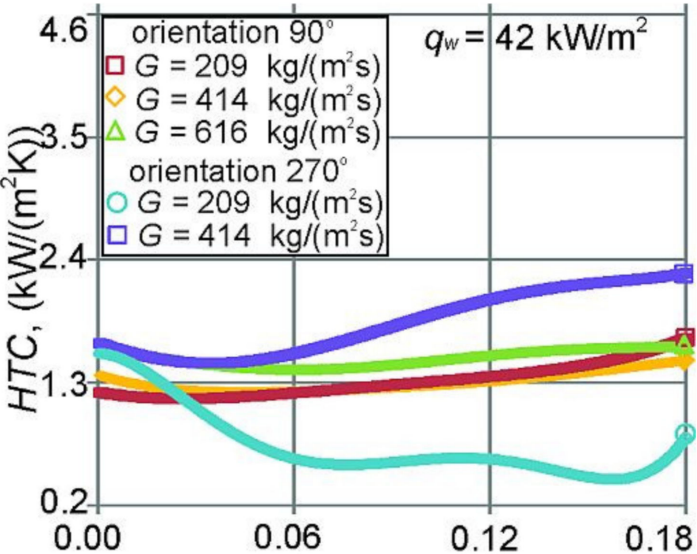

distance from the mini-channel inlet, $x(\mathrm{~m})$

(b)

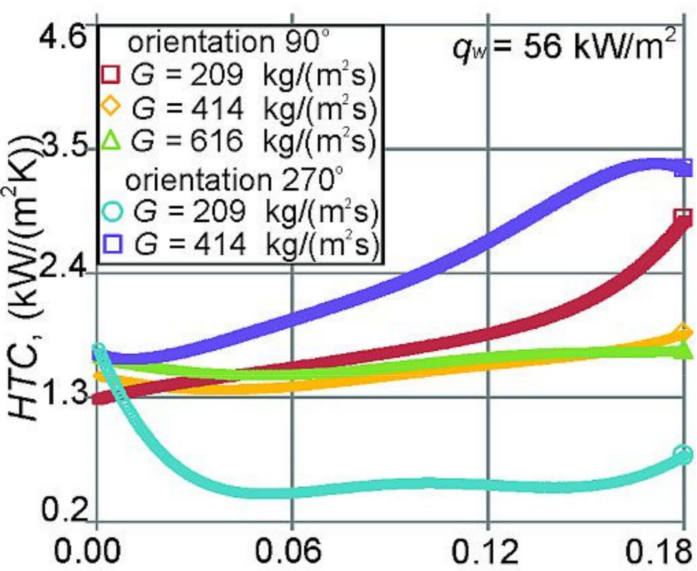

distance from the mini-channel inlet, $x(\mathrm{~m})$

(d)

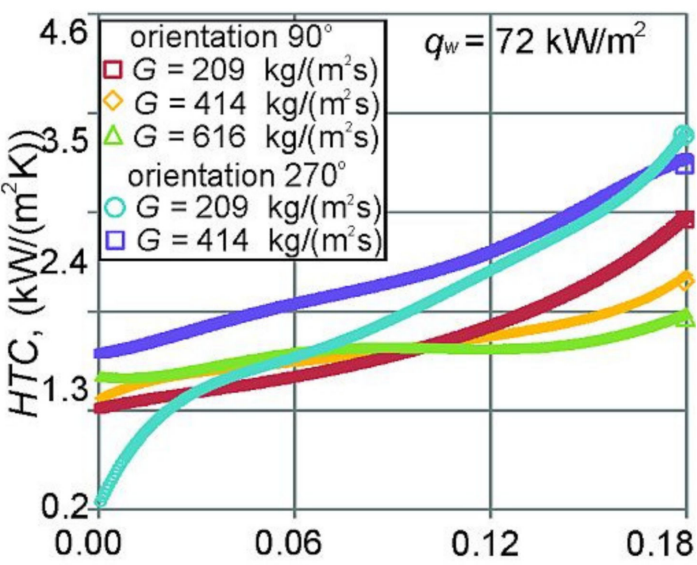

distance from the mini-channel inlet, $x(\mathrm{~m})$

(f)

Figure 7. Plate temperature measurements using the IR camera $(\mathbf{a}, \mathbf{c}, \mathbf{e})$ and heat transfer coefficient $(\mathbf{b}, \mathbf{d}, \mathbf{f})$, both vs. distance from the mini-channel inlet; subcooled boiling region; various mass fluxes; two vertical channel orientations $\left(90^{\circ}\right.$ and $\left.270^{\circ}\right)$; smooth heated plate; HFE-649; $L_{I R T}=180 \mathrm{~mm}$. 


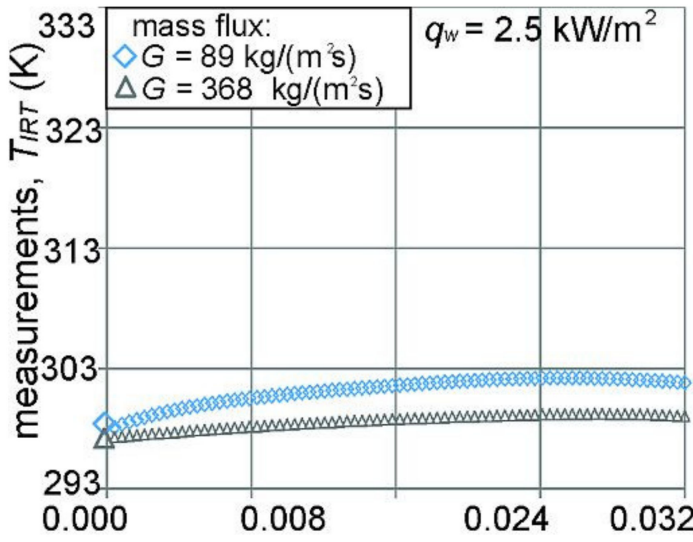

distance from the mini-channel inlet, $x(\mathrm{~m})$

(a)

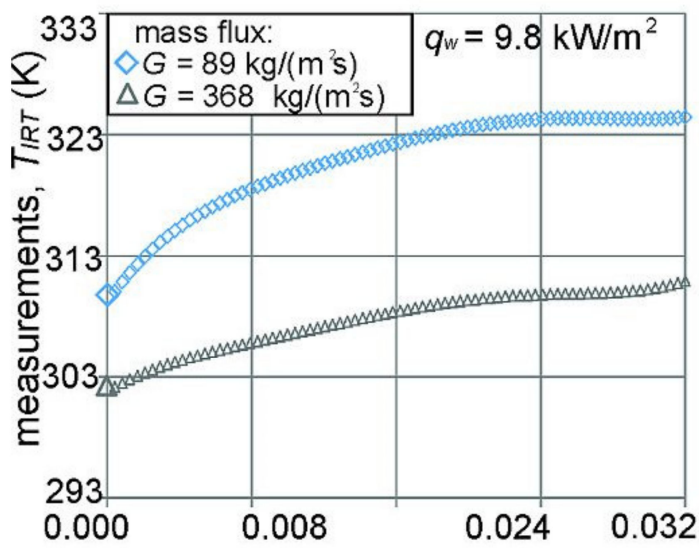

distance from the mini-channel inlet, $x(\mathrm{~m})$

(c)

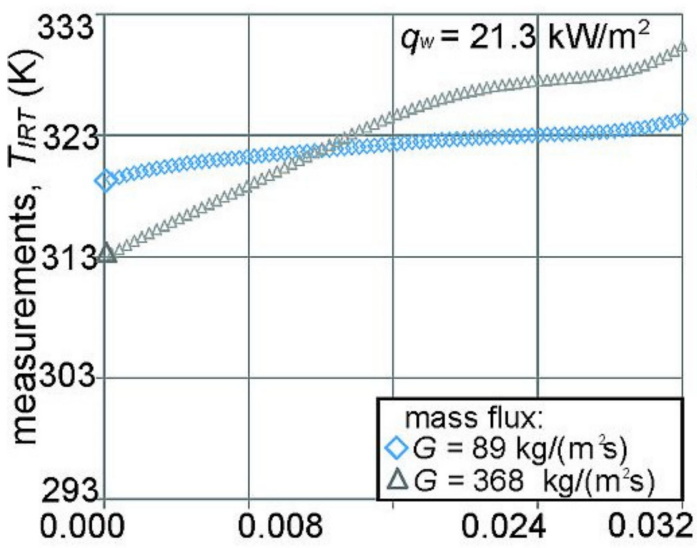

distance from the mini-channel inlet, $x(\mathrm{~m})$

(e)

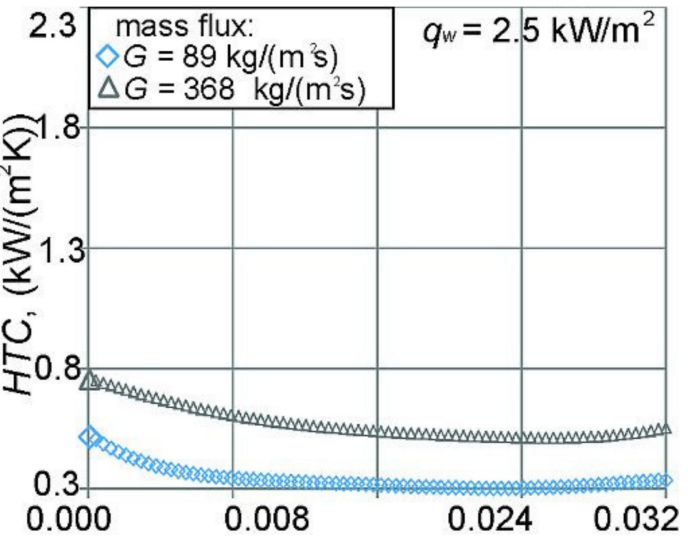

distance from the mini-channel inlet, $x(\mathrm{~m})$

(b)

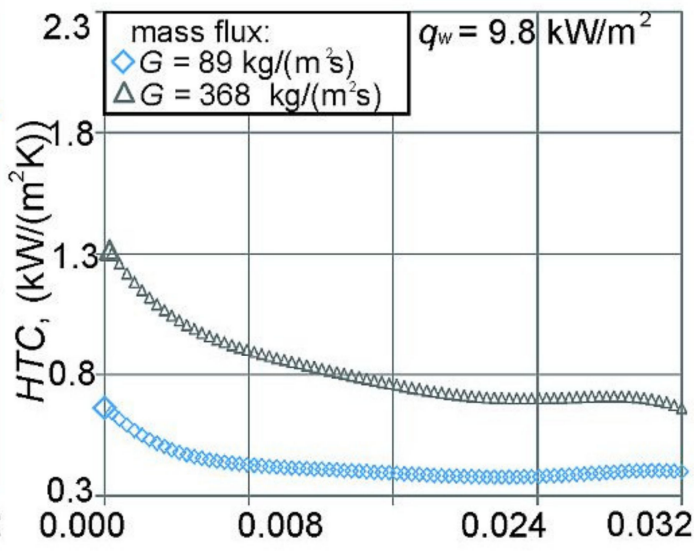

distance from the mini-channel inlet, $x(\mathrm{~m})$

(d)

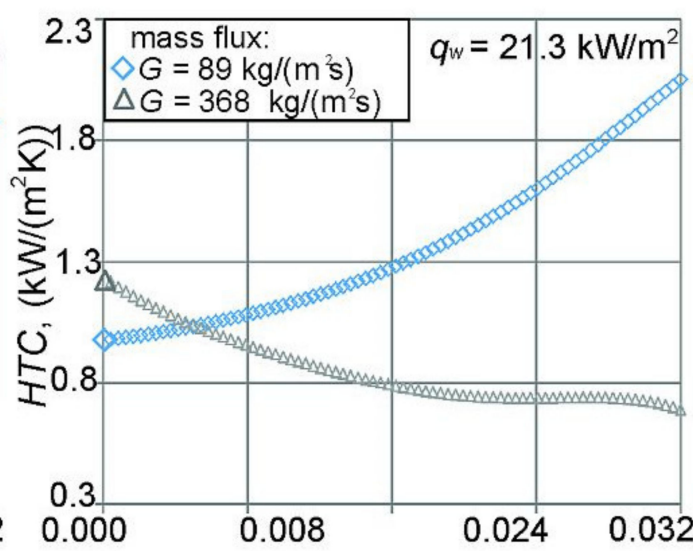

distance from the mini-channel inlet, $x(\mathrm{~m})$

(f)

Figure 8. Plate temperature measurements using the IR camera $(\mathbf{a}, \mathbf{c}, \mathbf{e})$ and heat transfer coefficient $(\mathbf{b}, \mathbf{d}, \mathbf{f})$, both vs. distance from the mini-channel inlet; subcooled boiling region; various mass fluxes; vertical channel orientation $\left(90^{\circ}\right)$; smooth heated plate; FC-72; $L_{I R T}=32 \mathrm{~mm}$. 


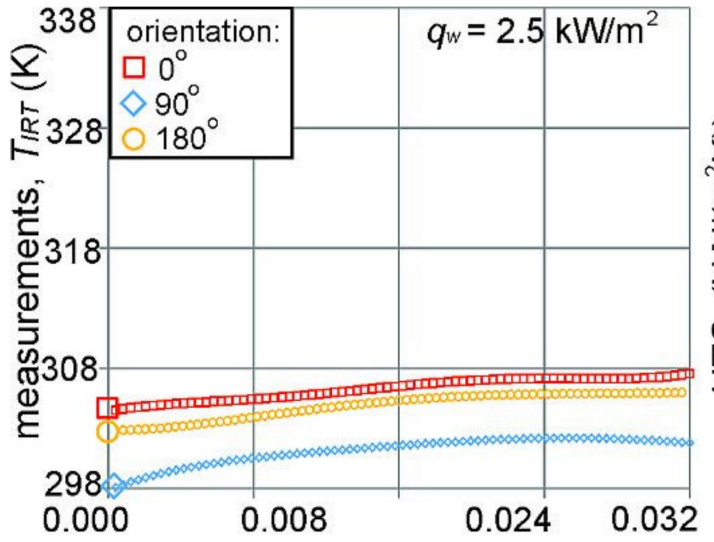

distance from the mini-channel inlet, $x(\mathrm{~m})$

(a)

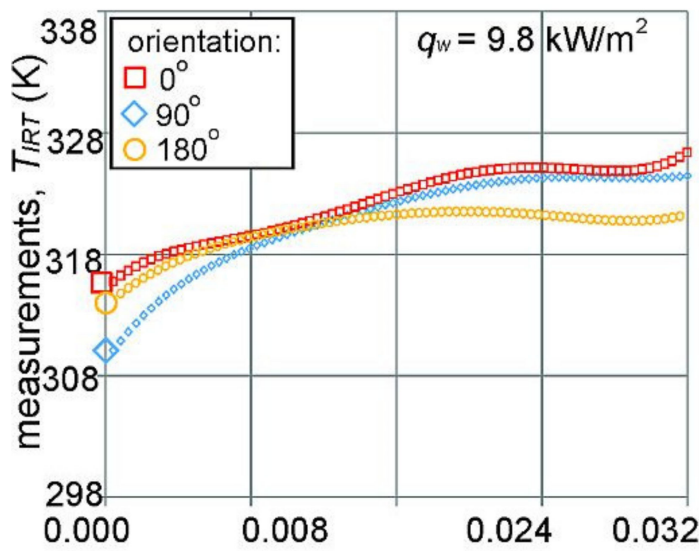

distance from the mini-channel inlet, $x(\mathrm{~m})$

(c)

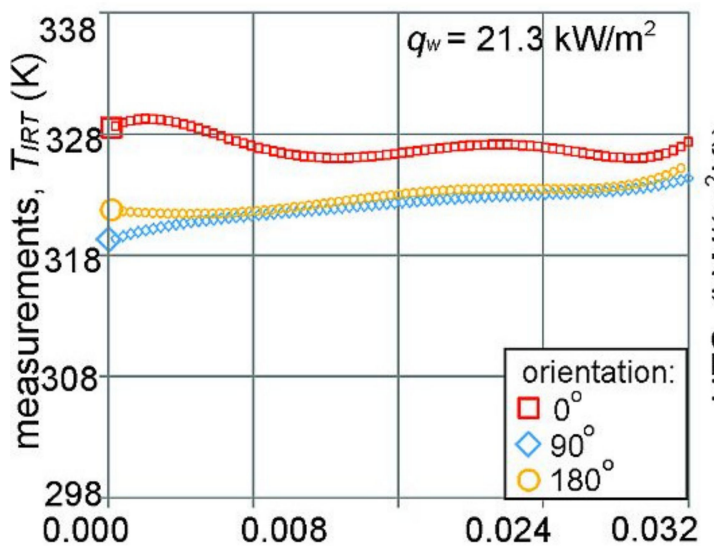

distance from the mini-channel inlet, $x(\mathrm{~m})$

(e)

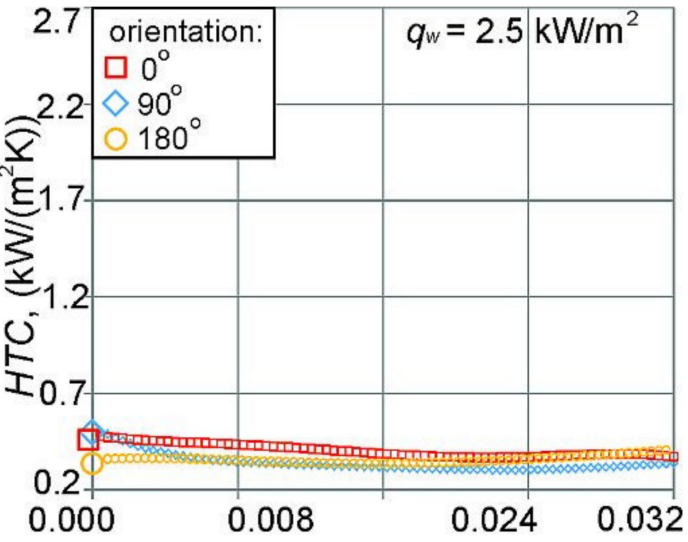

distance from the mini-channel inlet, $x(\mathrm{~m})$

(b)

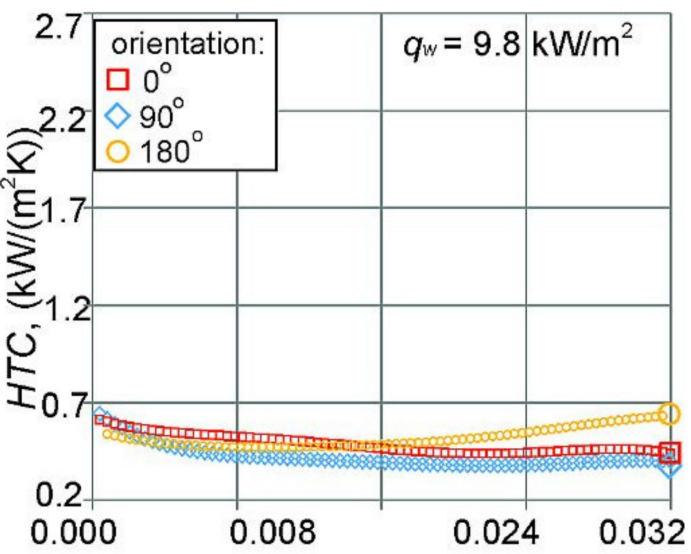

distance from the mini-channel inlet, $x(\mathrm{~m})$

(d)

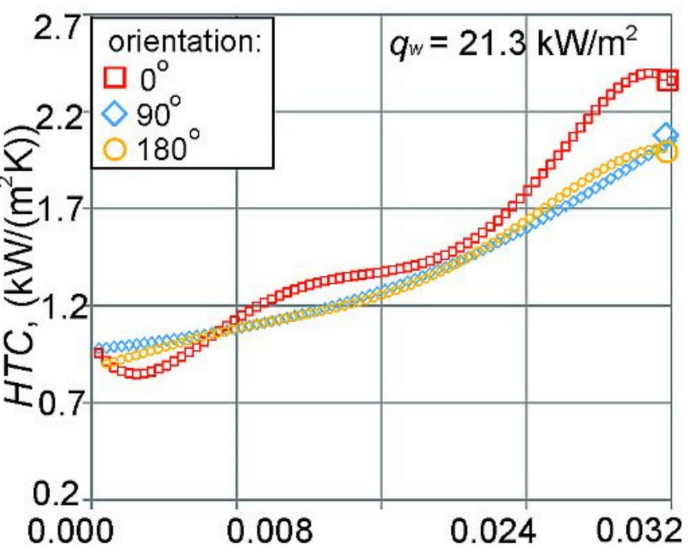

distance from the mini-channel inlet, $x(\mathrm{~m})$

(f)

Figure 9. Plate temperature measurements using the IR camera $(\mathbf{a}, \mathbf{c}, \mathbf{e})$ and heat transfer coefficient $(\mathbf{b}, \mathbf{d}, \mathbf{f})$, both vs. distance from the mini-channel inlet; subcooled boiling region; three spatial channel orientations $\left(0^{\circ}, 90^{\circ}\right.$ and $\left.180^{\circ}\right)$; mass flux of $440 \mathrm{~kg} /\left(\mathrm{m}^{2} \cdot \mathrm{s}\right)$, smooth heated plate; FC-72; $L_{I R T}=32 \mathrm{~mm}$. 

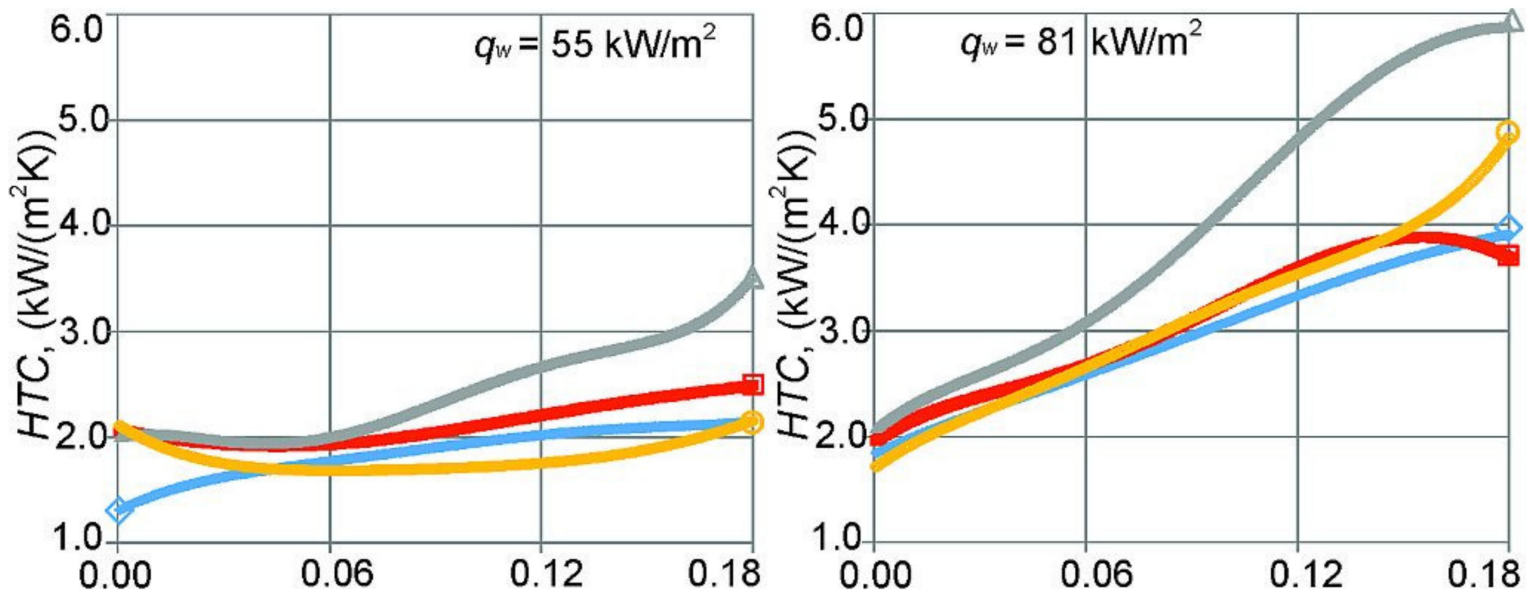

distance from the mini-channel inlet, $x(\mathrm{~m})$

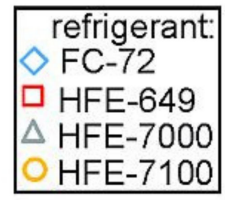

(a)

distance from the mini-channel inlet, $x(\mathrm{~m})$

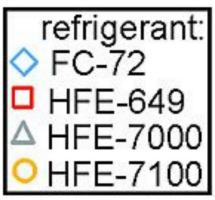

(b)
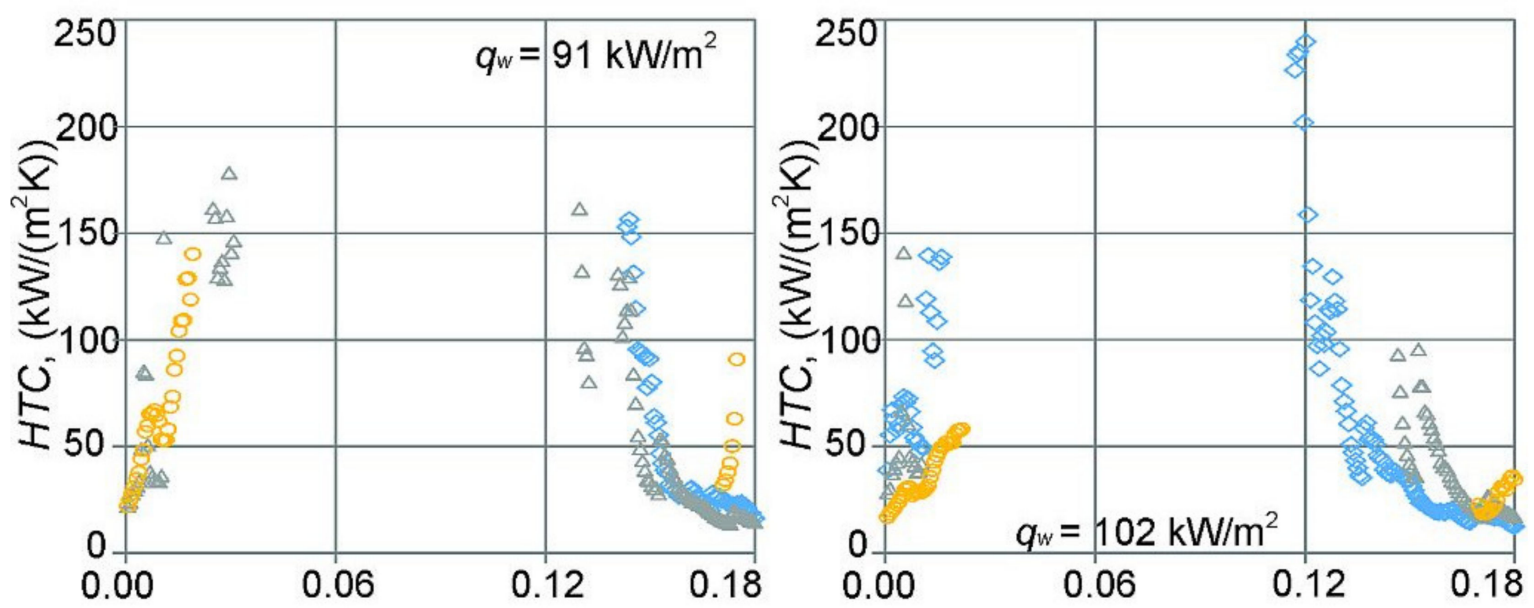

distance from the mini-channel inlet, $x(m)$

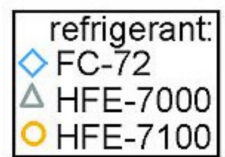

(c) distance from the mini-channel inlet, $x(\mathrm{~m})$

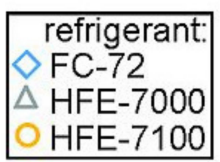

(d)

Figure 10. Heat transfer coefficient vs. distance from the mini-channel inlet: subcooled boiling region $(\mathbf{a}, \mathbf{b})$ and saturated boiling region (c,d); various refrigerants; vertical channel orientation $\left(90^{\circ}\right)$; average mass flux of $435 \mathrm{~kg} /\left(\mathrm{m}^{2} \cdot \mathrm{s}\right)$, modified heated plate surface (vibration-assisted laser surface texturing No. 2); FC-72; $L_{I R T}=180 \mathrm{~mm}$. 


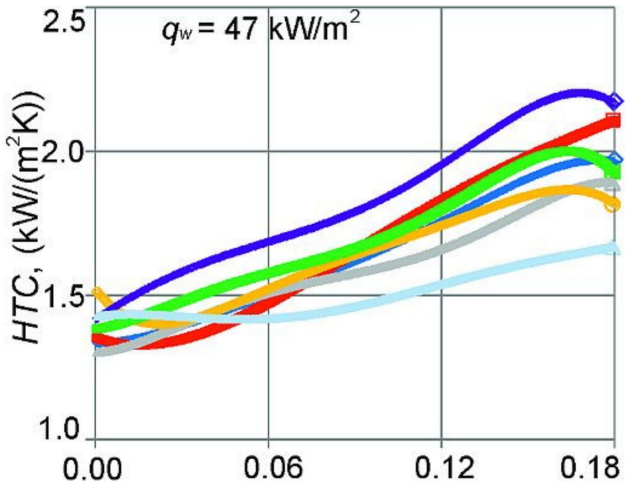

distance from the mini-channel inlet, $x(\mathrm{~m})$

\begin{tabular}{|l|}
\hline heated plate surface: \\
$\square$ smooth \\
$\diamond$ erosion \\
iron powder sol. \\
$\triangle$ iron powder sin. \\
$\diamond$ laser No. 1 \\
$\square$ laser No. 2 \\
$\triangle$ laser No. 3 \\
\hline
\end{tabular}

(a)

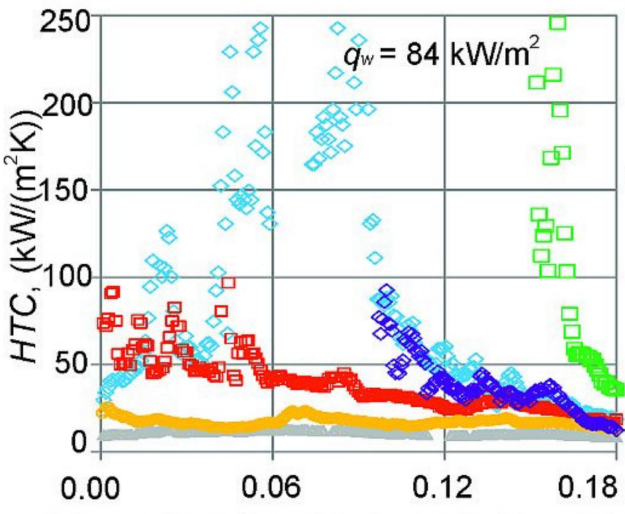

distance from the mini-channel inlet, $x(\mathrm{~m})$

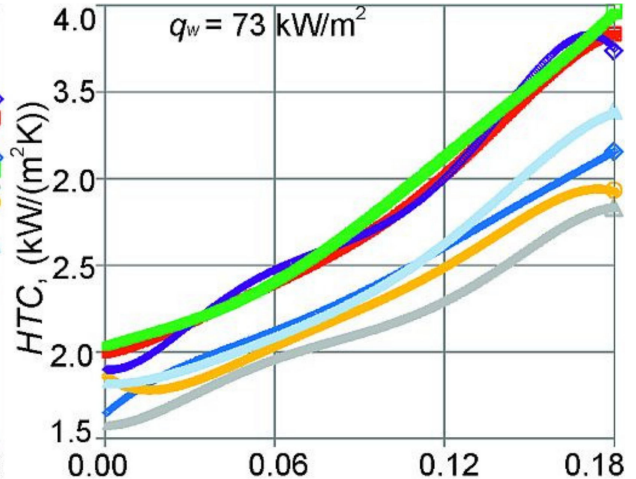

distance from the mini-channel inlet, $x(\mathrm{~m})$

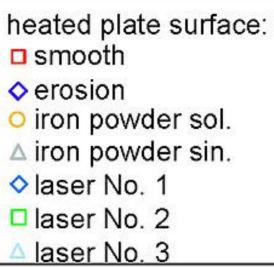

heated plate surface:

口 smooth

$\diamond$ erosion

iron powder sol.

$\triangle$ iron powder sin.

$\diamond$ laser No. 1

$\square$ laser No. 2

laser No. 3

\section{(b)}

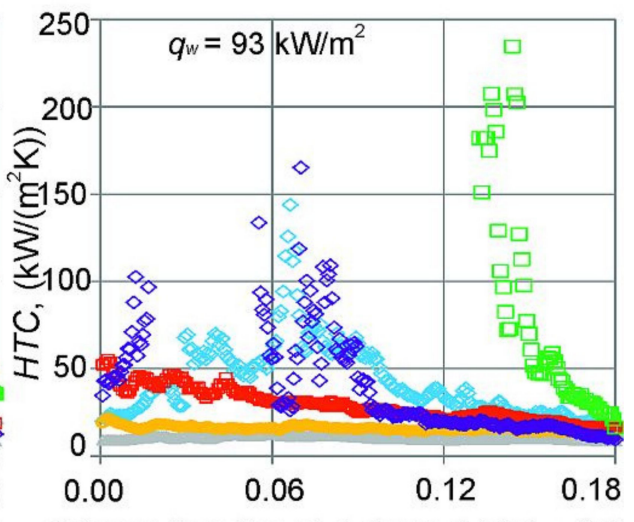

distance from the mini-channel inlet, $x(\mathrm{~m})$

\begin{tabular}{|l}
\hline heated plate surface: \\
$\square$ smooth \\
$\diamond$ erosion \\
0 iron powder sol. \\
$\triangle$ iron powder sin. \\
$\diamond$ laser No. 1 \\
$\square$ laser No. 2 \\
laser No. 3 \\
\hline
\end{tabular}

(c)

\begin{tabular}{|l|}
\hline heated plate surface: \\
$\square$ smooth \\
$\diamond$ erosion \\
$\diamond$ iron powder sol. \\
$\triangle$ iron powder sin. \\
$\diamond$ laser No. 1 \\
$\square$ laser No. 2 \\
$\triangle$ laser No. 3 \\
\hline
\end{tabular}

(d)

Figure 11. Heat transfer coefficient vs. distance from the mini-channel inlet: subcooled boiling region $(\mathbf{a}, \mathbf{b})$ and saturated boiling region (c,d); smooth and several modified heated plate surfaces; vertical channel orientation $\left(90^{\circ}\right)$; average mass flux of $353 \mathrm{~kg} /\left(\mathrm{m}^{2} \cdot \mathrm{s}\right) ; \mathrm{FC}-72 ; L_{I R T}=180 \mathrm{~mm}$.

\subsection{The Results-Analysis and Observations}

As in most scientific works, the results of heat transfer are presented in the form of temperature graphs, HTC, flow structures and boiling curves.

Selected data from the experiments are compiled as the relationship between:

- Heated plate temperature (HPT) due to the IR camera and the distance from the mini-channel inlet-in Figures 5-9 (parts "a", "c" and "e"), 
- Heat transfer coefficient (HTC) and the distance from the mini-channel inlet-in Figures 5-9 (parts " $\mathrm{b}$ ", " $\mathrm{d}$ " and " $\mathrm{f}$ "), and Figures 10 and 11, at subcooled and saturated boiling regions, separately.

Selected two-phase flow structures showing characteristic data are also illustrated graphically in Figures 12-15.

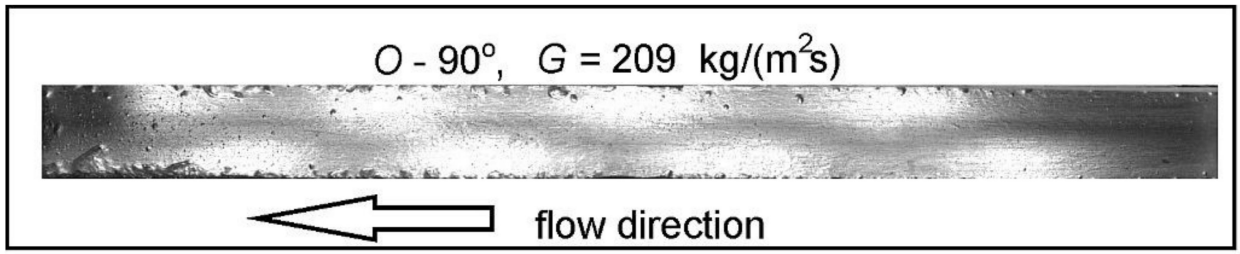

(a)

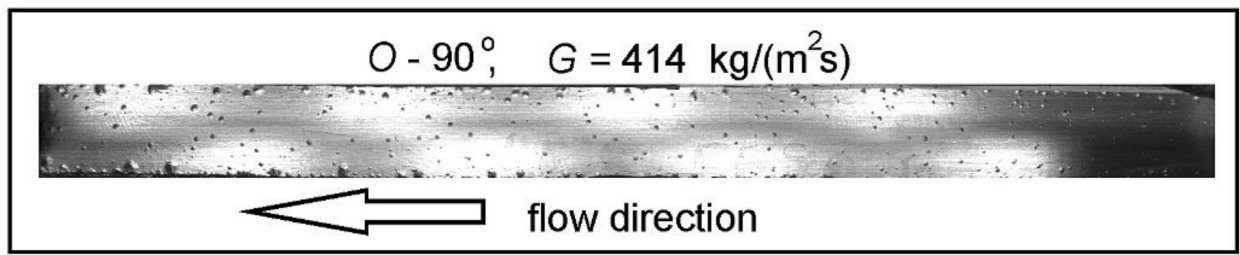

(b)

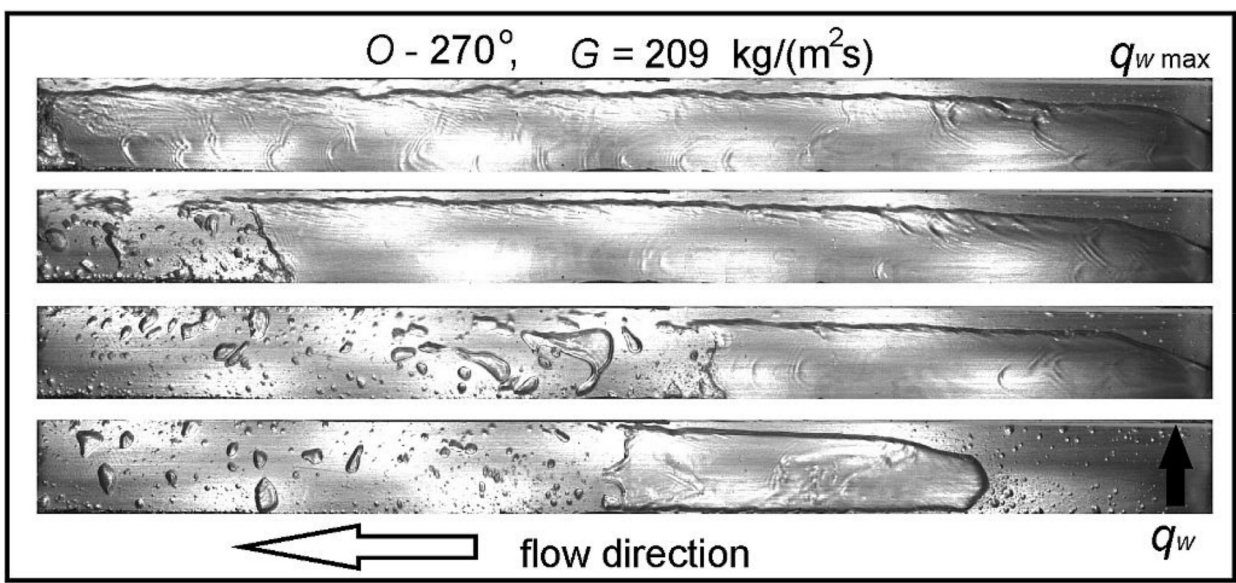

(c)

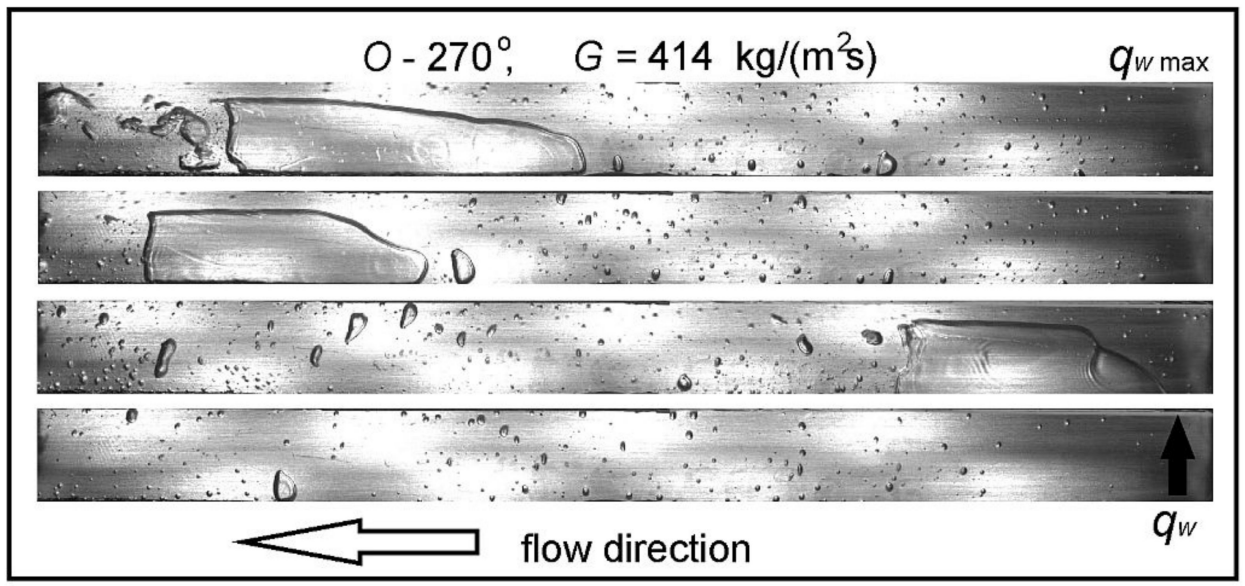

(d)

Figure 12. Images of two-phase flow structures recorded for: various mass fluxes and two vertical channel orientations $\left(90^{\circ}\right.$ and $\left.270^{\circ}\right)$, HFE-649, smooth heated plate, $L_{I R T}=180 \mathrm{~mm}$. 


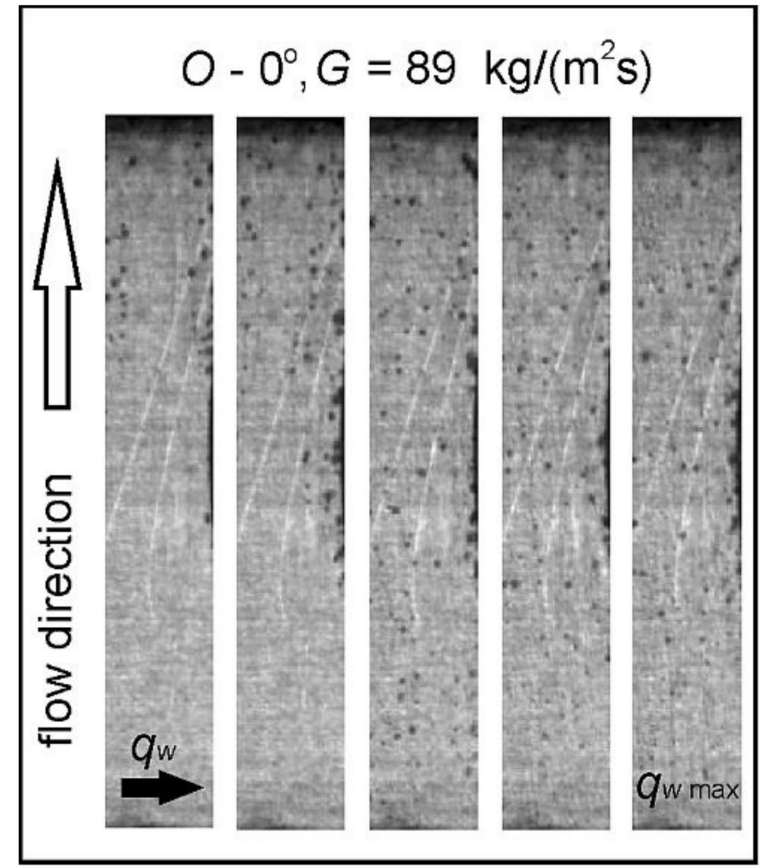

(a)

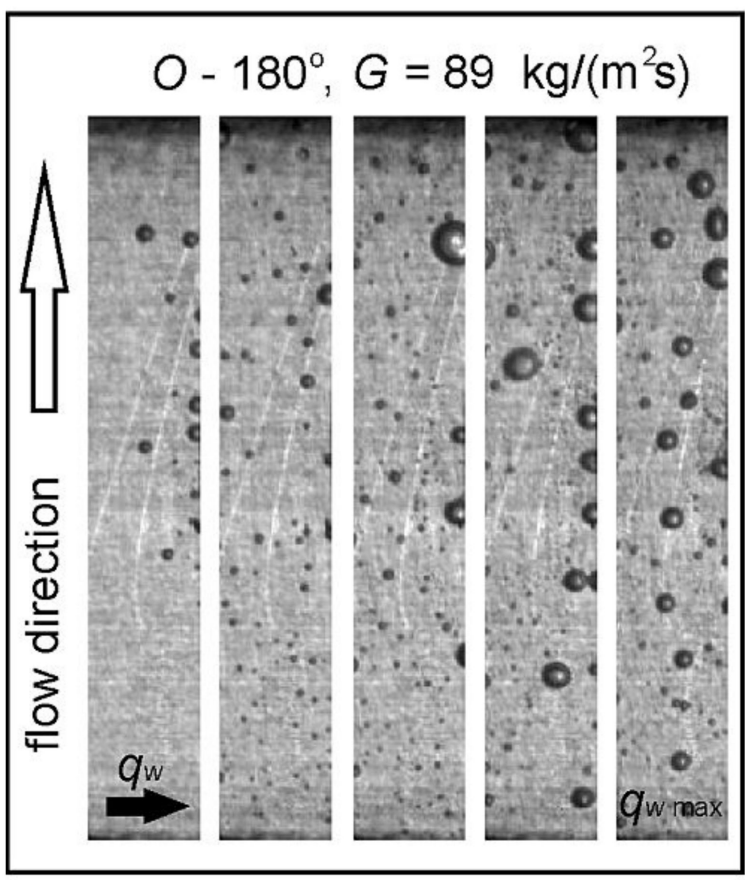

(c)

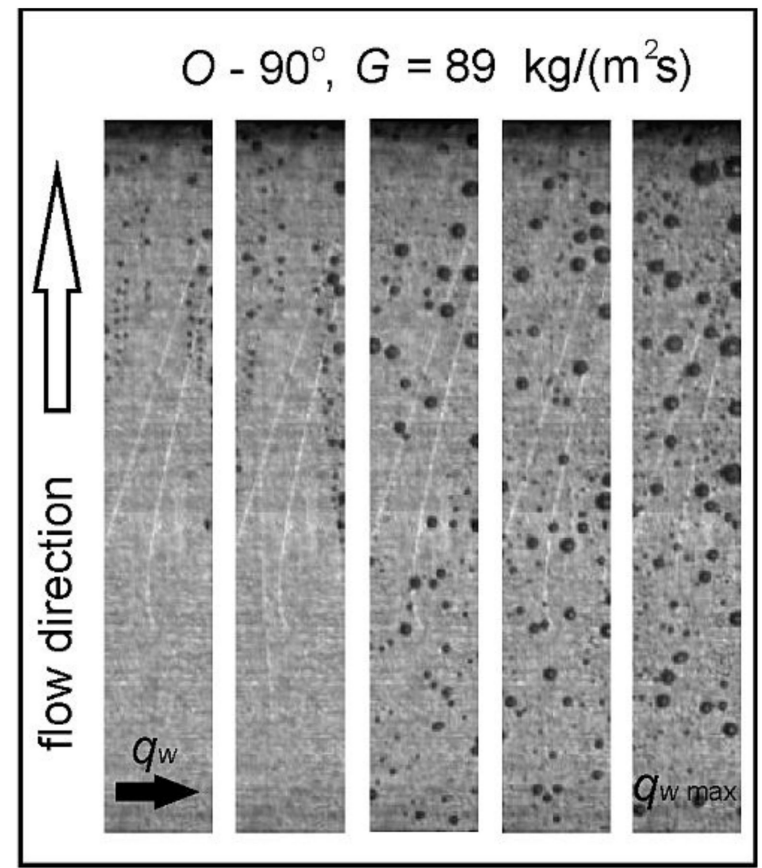

(b)

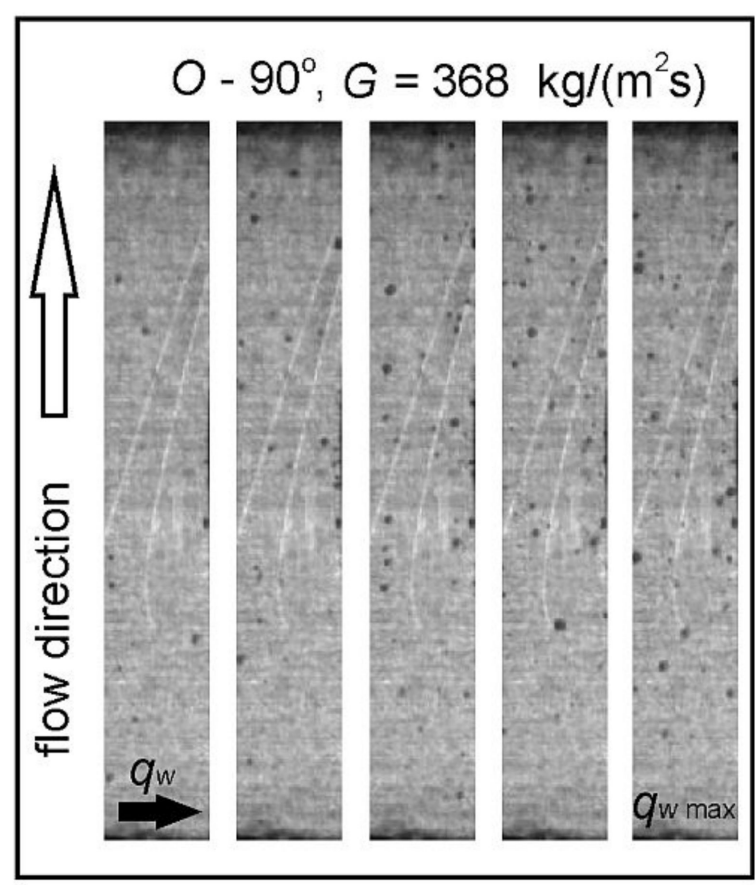

(d)

Figure 13. Images of two-phase flow structures recorded for: various mass fluxes and three channel orientations $\left(0^{\circ}, 90^{\circ}\right.$ and $\left.180^{\circ}\right)$, FC-72, smooth heated plate, $L_{I R T}=32 \mathrm{~mm}$. 


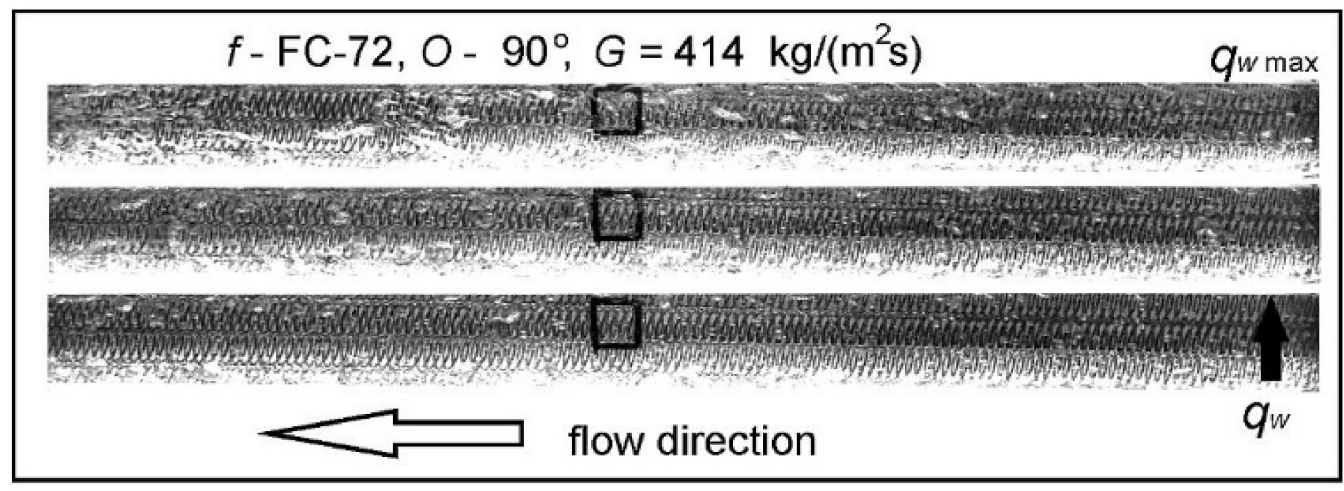

(a)

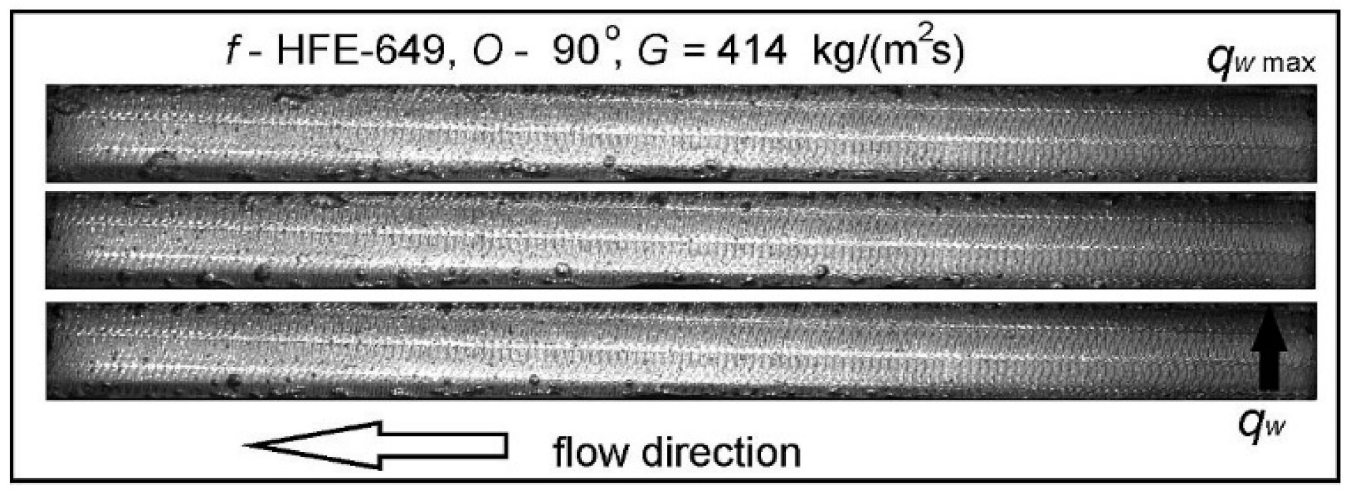

(b)

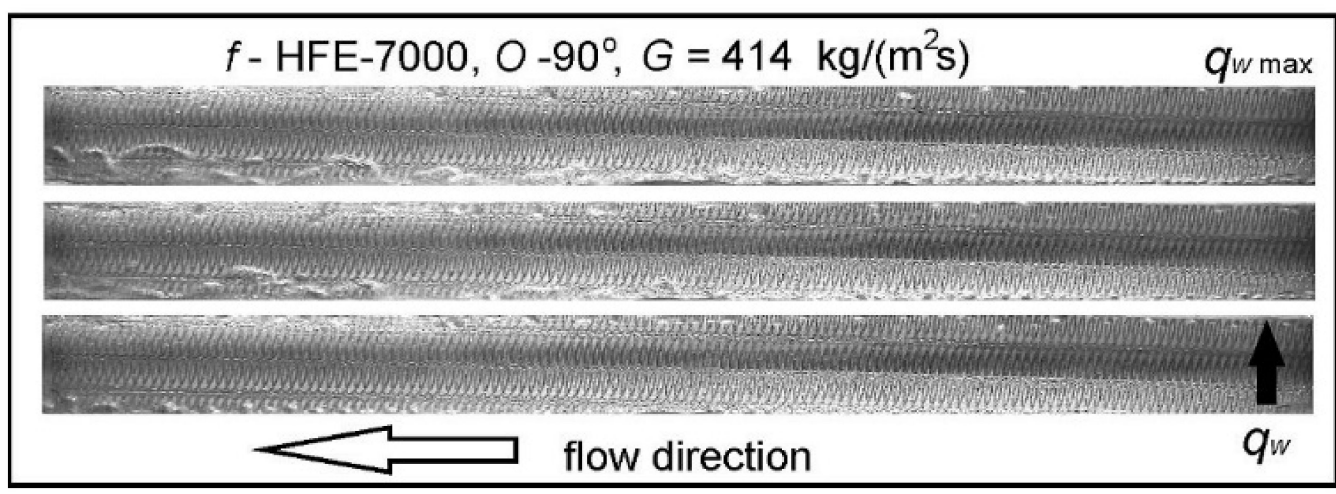

(c)

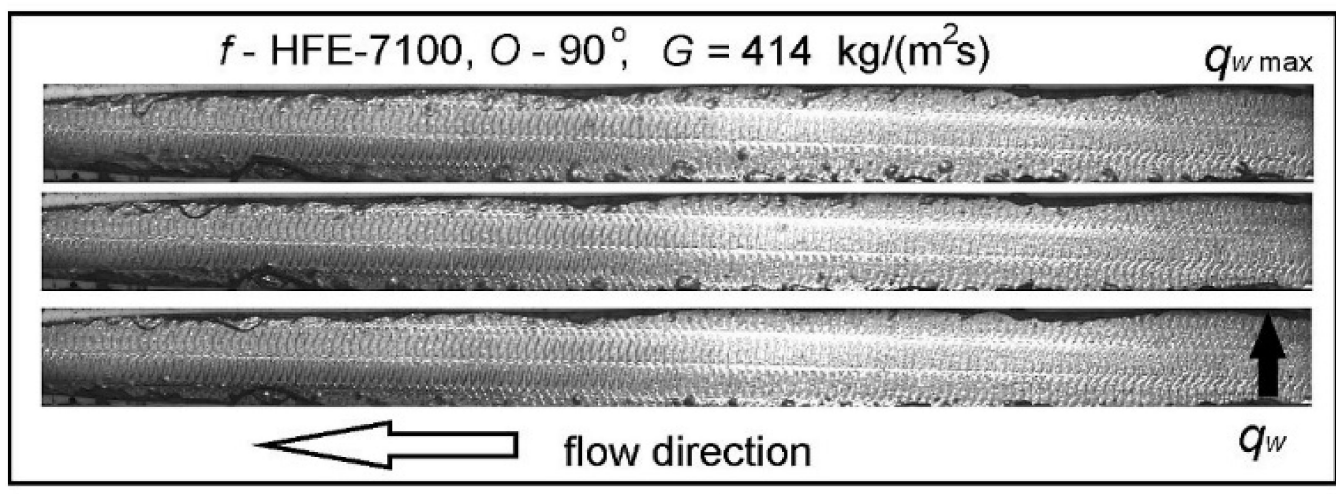

(d)

Figure 14. Images of two-phase flow structures recorded for: various refrigerants, constant mass flux, vertical channel orientation $\left(90^{\circ}\right)$, modified heated plate surface (vibration-assisted laser surface texturing No. 2), $L_{I R T}=180 \mathrm{~mm}$. 


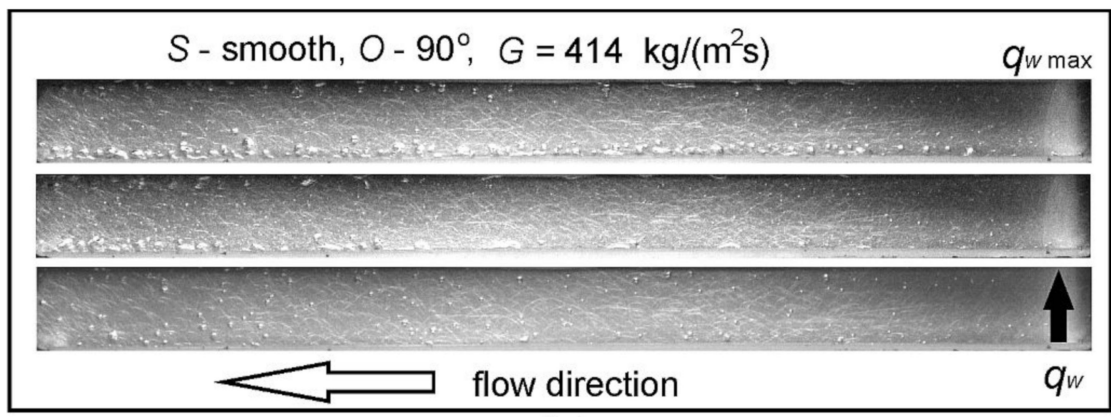

(a)

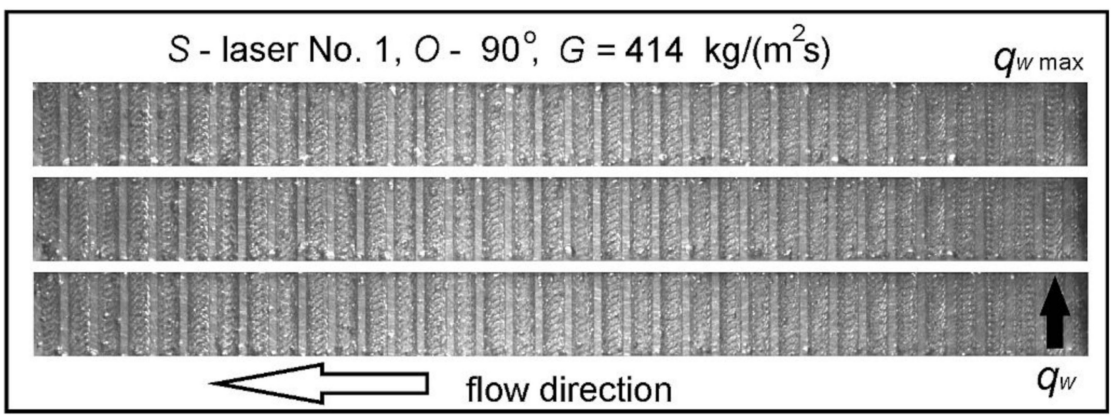

(b)

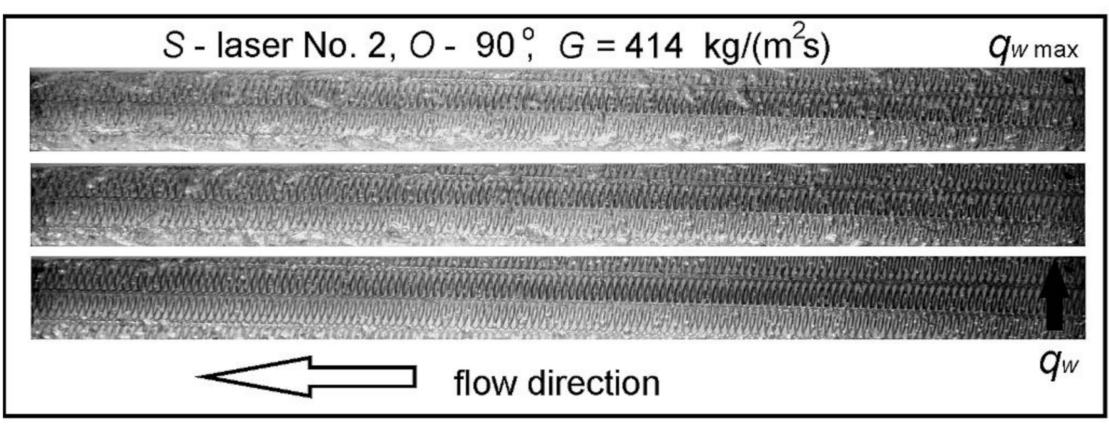

(c)

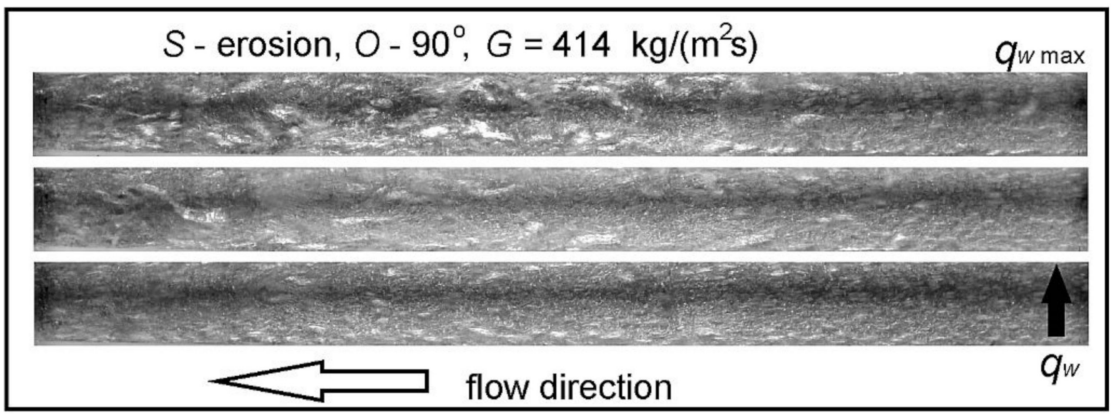

(d)

Figure 15. Images of two-phase flow structures recorded for: various modified heated plates, constant mass flux, vertical channel orientation $\left(90^{\circ}\right), \mathrm{FC}-72, L_{I R T}=180 \mathrm{~mm}$.

Comprehensive characteristics of the influence of selected factors on boiling heat transfer during flow in mini-channels are shown in Table 6. A database of selected experiments showing the main information concerning the investigations was listed in Table 5. It is worth underlining that at the subcooled boiling region, HTC was relatively low in comparison to HTC obtained at the saturated boiling region. 
Table 6. Characteristics of the influence of selected factors on flow boiling in mini-channels.

\begin{tabular}{|c|c|c|c|c|}
\hline Tested Factor & Main Experimental Data & $H P T$ & HTC & Flow Structures \\
\hline $\begin{array}{l}\text { Inlet pressure } \\
\left(p_{\text {in }}\right)\end{array}$ & $\begin{array}{l}L_{I R T}=180 \mathrm{~mm} \\
S \text {-v.a. las. } 2 \\
f \text {-HFE- } 649 \\
O-90^{\circ}\end{array}$ & $\begin{array}{l}\text { Figure } 5 \mathrm{a}, \mathrm{c}, \mathrm{e} \\
\text { - } \quad \text { Higher } H P T \text { at higher } p_{i n} \text {, for all } q_{w}\end{array}$ & $\begin{array}{l}\text { Figure } 5 \mathrm{~b}, \mathrm{~d}, \mathrm{f} \text { (subcooled boiling region) } \\
\text { - } \quad \text { The highest } H T C \text { at lower } p_{i n} \text { for all } q_{w} \\
\text { - } \quad \text { Slightly higher HTC at lower } p_{i n} \text { for higher } q_{w} \\
\text { (Figure } 5 \mathrm{~d}, \mathrm{f}) \\
\text { - } \quad \text { HTC increase with the distance from the } \\
\text { channel inlet at all } p_{\text {in }} \text { for all } q_{w} \\
\text { - Similar } H T C \text { distribution }\end{array}$ & $\begin{array}{l}\text { Remarks based on experiments } \\
\text { - } \quad \text { More vapor bubbles in the two-phase pattern } \\
\text { observed at lower } p_{i n} \\
\text { - } \quad \text { Tiny bubbles observed only at higher } p_{i n} \text { for } \\
\text { higher } q_{w}\end{array}$ \\
\hline $\begin{array}{l}\text { Mass } \\
\text { flux }(G)\end{array}$ & $\begin{array}{l}L_{I R T}=180 \mathrm{~mm} \\
S-\text { smooth } \\
f-\text { FC-72 } \\
f-\text { HFE- } 649 \\
O-90^{\circ}\end{array}$ & $\begin{array}{l}\text { Figure } 6 \mathrm{a}, \mathrm{c}, \mathrm{e}(\mathrm{FC}-72) \\
-\quad \text { Higher HPT for the lowest } G \text {, for all } q_{w} \\
\text { - The lowest HPT for the highest } G \text { at the } \\
\text { channel inlet, for lower } q_{w} \text { (Figure 6a,c) }\end{array}$ & $\begin{array}{l}\text { Figure } 6 \mathrm{~b}, \mathrm{~d}, \mathrm{f} \text { (subcooled boiling region, FC-72) } \\
\text { - The highest } H T C \text { for the lowest } G \text { and higher } q_{w} \\
\text { at the channel outlet (Figure } 6 \mathrm{~d}, \mathrm{f} \text { ) } \\
\text { - Slight impact } G \text { on } H T C \text { for the lowest } q_{w,} \\
\text { (Figure } 6 \mathrm{~b} \text { ) } \\
\text { - HTC increase with the distance from the } \\
\text { channel inlet for higher } q_{w,}(\text { Figure } 6 \mathrm{~b}, \mathrm{~d})\end{array}$ & $\begin{array}{l}\text { Figure 12a,b (HFE-649) } \\
\text { - } \quad \text { Only tiny vapor bubbles observed near channel } \\
\text { side walls at the outlet } \\
\text { - Larger bubbles observed near channel side walls } \\
\text { for the lowest } G \text { (Figure 12a) }\end{array}$ \\
\hline $\begin{array}{l}\text { Mass } \\
\text { flux }(\mathrm{G}) \\
\text { orientation }(\mathrm{O})\end{array}$ & $\begin{array}{l}L_{I R T}=180 \mathrm{~mm} \\
S-\text { smooth } \\
f-\text { HFE- } 649 \\
O-90^{\circ}, 270^{\circ}\end{array}$ & $\begin{array}{l}\text { Figure } 7 \mathrm{a}, \mathrm{c}, \mathrm{e} \\
\text { - The highest } H P T \text { for the lowest } G \text { and } \\
\text { lower } q_{w}, \text { for } O-270^{\circ} \text { (Figure } 7 \mathrm{a}, \mathrm{c} \text { ) } \\
\text { - Higher } H P T \text { for the lowest } G \text { and all } q_{w} \text {, } \\
\text { for } O-90^{\circ} \\
\text { - The lowest } H T P \text { for higher } G \text { and all } q_{w} \text {, } \\
\text { for } O-270^{\circ}\end{array}$ & $\begin{array}{l}\text { Figure } 7 \mathrm{~b}, \mathrm{~d}, \mathrm{f} \text { (subcooled boiling region) } \\
\text { - } \quad \text { The highest } H T C \text { for higher } G \text { and all } q_{w} \text {, for } \\
O-270^{\circ} \\
\text { - } \quad \text { The lowest } H T C \text { for lower } G \text { and lower } q_{w} \text {, for } \\
\quad O-270^{\circ} \\
\text { - } \quad \text { Slight impact } q_{w} \text { on } H T C \text {, for } O-90^{\circ}\end{array}$ & $\begin{array}{l}\text { Figure 12a-d } \\
\text { - } \quad \begin{array}{l}\text { Only tiny, single vapor bubbles observed near } \\
\text { channel side walls at the outlet, for } O-90^{\circ}\end{array} \\
\text { - } \quad \text { More gaseous phase, locally elongated } \\
\text { agglomerates, for } O-270^{\circ} \\
\text { - } \quad \begin{array}{l}\text { Developed annular structures formed near the } \\
\text { channel inlet, for } O-270^{\circ}[31]\end{array} \\
\text { - } \quad \begin{array}{l}\text { Elongated vapor agglomerates causing sudden } \\
\text { changes in } H T P \text { and } H T C, \text { for } O-270^{\circ}\end{array}\end{array}$ \\
\hline $\begin{array}{l}\text { Mass flux } \\
(G)\end{array}$ & $\begin{array}{l}L_{I R T}=32 \mathrm{~mm} \\
S-\text { smooth } \\
f-\mathrm{FC}-72 \\
O-90^{\circ}\end{array}$ & $\begin{array}{l}\text { Figure } 8 \mathrm{a}, \mathrm{c}, \mathrm{e} \\
\text { - The highest } H P T \text { for lower } G \text { and lower } \\
\text { - } \quad q_{w} \text { (Figure } 8 \mathrm{a}, \mathrm{c} \text { ) } \\
\text { The above remark confirms the results } \\
\text { for a longer mini-channel } L_{I R}=180 \mathrm{~mm} \\
\text { (Figure } 6 \mathrm{a}, \mathrm{c}, \mathrm{e})\end{array}$ & $\begin{array}{l}\text { Figure } 8 \mathrm{~b}, \mathrm{~d}, \mathrm{f} \text { (subcooled boiling region) } \\
\text { - } \quad \text { The highest } H T C \text { for higher } G \text { and lower } q_{w} \\
\text { (Figure } 8 \mathrm{~b}, \mathrm{~d} \text { ) } \\
\text { - } \quad \text { The highest } H T C \text { for lower } G \text { and the highest } q_{w} \\
\text { (Figure } 8 \mathrm{f} \text { ) } \\
\text { - } \quad \text { HTC decrease with the distance from the } \\
\text { channel inlet for lower } q_{w} \text { (Figure } 8 \mathrm{~b}, \mathrm{~d} \text { ) }\end{array}$ & $\begin{array}{l}\text { Figure } 13 \mathrm{~b}, \mathrm{~d} \\
\text { - } \quad \text { Increasing amount of vapor bubbles and their } \\
\text { dynamic formation with } q_{w} \text { increase, for lower } G \\
\text { - More spherical bubbles of larger size for the } \\
\text { lowest } G \text { (Figure } 13 \mathrm{~b} \text { ) } \\
\text { - Only tiny single bubbles observed mainly at the } \\
\text { channel outlet, for higher } G \text { and higher } q_{w} \\
\text { (Figure 13d) }\end{array}$ \\
\hline
\end{tabular}


Table 6. Cont

\begin{tabular}{|c|c|c|c|c|}
\hline Tested Factor & Main Experimental Data & HPT & HTC & Flow Structures \\
\hline Orientation $(\mathrm{O})$ & $\begin{array}{l}L_{I R T}=32 \mathrm{~mm} \\
S-\text { smooth } \\
f-\mathrm{FC}-72 \\
\mathrm{O}-0^{\circ}, 90^{\circ}, 180^{\circ}\end{array}$ & $\begin{array}{l}\text { Figure } 9 \text { a,c,e } \\
\text { - The highest } H P T \text { for } O-0^{\circ} \text { for all } q_{w} \\
\text { - The lowest } H T P \text { for } O-90^{\circ} \text { and the } \\
\text { lowest } q_{w} \text { (Figure } 9 \text { a) } \\
\text { - Similar } H P T \text { for the highest } q_{w} \text { for } \\
\quad O-90^{\circ} \text { and } O-180^{\circ}\end{array}$ & $\begin{array}{l}\text { Figure } 9 \mathrm{~b}, \mathrm{~d}, \mathrm{f} \text { (subcooled boiling region) } \\
\text { - } \quad H T C \text { increase with the distance from the } \\
\text { channel inlet (Figure } 9 \mathrm{f} \text { ) } \\
\text { The highest } H T C \text { for the highest } q_{w} \text {, for } O-0^{\circ} \\
\text { (Figure } 9 \mathrm{f} \text { ) } \\
\text { - Relatively minor differences in } H T C \text { with the } \\
\text { channel distance for lower } q_{w} \text {, for all } \\
\text { orientations (Figure } 9 \mathrm{~b}, \mathrm{~d} \text { ) }\end{array}$ & $\begin{array}{l}\text { Figure } 13 \mathrm{a}, \mathrm{b}, \mathrm{c} \\
\text { - The greatest size of bubbles, for } \mathrm{O}-180^{\circ} \\
\text { (Figure 13c) } \\
\text { - The lowest and the least fragmented bubbles, for } \\
\mathrm{O}-0^{\circ} \text { (Figure 13a) }\end{array}$ \\
\hline Fluid $(f)$ & $\begin{array}{l}L_{I R T}=180 \mathrm{~mm} \\
S-\text { v.a. las. } 2 \\
f \text {-FC-72 } \\
\text { HFE-649 } \\
\text { HFE-7000 } \\
\text { HFE-7100 } \\
O-90^{\circ}\end{array}$ & - & $\begin{array}{l}\text { Figure 10a,b (subcooled boiling region) } \\
\text { - } \quad H T C \text { increase with the distance from the } \\
\text { channel inlet for all fluids, lower HTC in } \\
\text { comparison to those obtained at saturated } \\
\text { boiling region }[19,22] \\
\text { - The highest } H T C \text { for HFE-7000, for all } q_{w} \\
\text { The lowest } H T C \text { for HFE-7100, for lower } q_{w} \\
\text { despite the channel inlet (Figure 10a) }\end{array}$ & $\begin{array}{l}\text { Figure 14a-d } \\
\text { - Higher share of vapor in two-phase structures } \\
\text { and more developed vapor structures as } \\
\text { elongated agglomerates, observed for FC-72 in } \\
\text { comparison to other refrigerants (Figure 14a) } \\
\text { - Bubbly, bubbly-slug or slug structures observed } \\
\text { for HFE-7000 [19] (Figure 14c) }\end{array}$ \\
\hline Fluid $(f)$ & $\begin{array}{l}L_{I R T}=180 \mathrm{~mm} \\
S-\text { v.a. las. } 2 \\
\text { f-FC-72 } \\
\text { HFE-7000, } \\
\text { HFE-7100 } \\
O-90^{\circ}\end{array}$ & - & $\begin{array}{l}\text { Figure } 10 \mathrm{c}, \mathrm{d} \text { (saturated boiling region) } \\
\text { - The highest } H T C \text { at saturated boiling region, } \\
\text { confirming previous results }[19,22] \\
\text { - The highest } H T C \text { for FC-72 and HFE-7000, for } \\
\text { all } q_{w w} \text {, which confirms the results shown in [19] } \\
\text { - The lowest HTC for HFE-7100 for higher } q_{w} \\
\text { (Figure 10d) }\end{array}$ & $\begin{array}{l}\text { Figure } 14 \mathrm{a}-\mathrm{d} \\
\text { - Only single bubbles visible for HFE- } 649 \text { and } \\
\text { HFE-7100, mainly near the side walls, at the } \\
\text { channel outlet (Figure } 14 \mathrm{~b}, \mathrm{~d} \text { ) } \\
\text { The least numerous bubbles observed for the HFE- } 649 \\
\text { (Figure } 14 \mathrm{~b} \text { ) }\end{array}$ \\
\hline
\end{tabular}


Table 6. Cont.

Main Experimental Data $2-H P T$

Figure 11a,b (subcooled boiling region)

- The highest $H T C$ for electroerosion and vibration-assisted laser No. 2 surface texturing for higher $q_{w}$, confirming the results discussed in [32]

$\begin{array}{ll}\text { Heated } & S-\text { smooth } \\ \text { plate } & \text { v.a. las. 1,2,3, electr., sold. } \\ \text { surface }(S) & \text { and sin. i.p. } \\ & f-\text { FC-72 } \\ & O-90^{\circ}\end{array}$

- The lowest $H T C$ for vibration-assisted laser No. 3 surface

Flow Structures texturing for lower $q_{w}$ (Figure 11a) and porous surfaces produced by sintering iron powder for higher $q_{w}$ (Figure 11b)

- Higher HTC for higher $q_{w}$, for the surface produced by soldering iron powder [23]

Figure $11 \mathrm{c}, \mathrm{d}$ (saturated boiling region)

- The highest HTC for electroerosion and vibration-assisted laser No. 2 surface texturing, similarly as in [32]

$\begin{array}{ll} & L_{I R T}=180 \mathrm{~mm} \\ \text { Heated } & S-\text { smooth } \\ \text { plate } & \text { v.a. las. 1,2,3, electr., sold. and sin. i.p. } \\ \text { surface }(S) & f-\text { FC-72 } \\ & O-90^{\circ}\end{array}$

- $\quad$ Lower HTC for porous metal surfaces produced by soldering and sintering iron powder in comparison to other tested surfaces, for all $q_{w}$ According to [32]

- Very low HTC for porous metal surfaces with capillary-fibrous structures

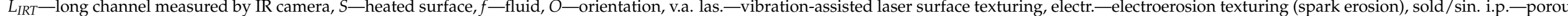

metal surfaces produced by soldering and sintering iron powder.
}

- Spherical and tiny bubbles observed for a smooth heated plate (Figure 15a)

- $\quad$ Small spherical bubbles observed for vibration-assisted laser No. 1 surface texturing(Figure 15b)

- Bubbles of larger size and elongated agglomerates observed for the vibration-assisted laser No. 2 surface texturing (Figure 15c)

The highest vapor share in two-phase flow structures with elongated agglomerates in comparison to other tested plate surfaces, observed for electroerosion surface texturing(Figure 15d) 
Boiling curves are essential to recognize heat transfer mechanisms in flow boiling. The boiling curves shown in Figure 16 were generated on the basis of the experimental data during increasing heat flux supplied to the mini-channel's heated plate.

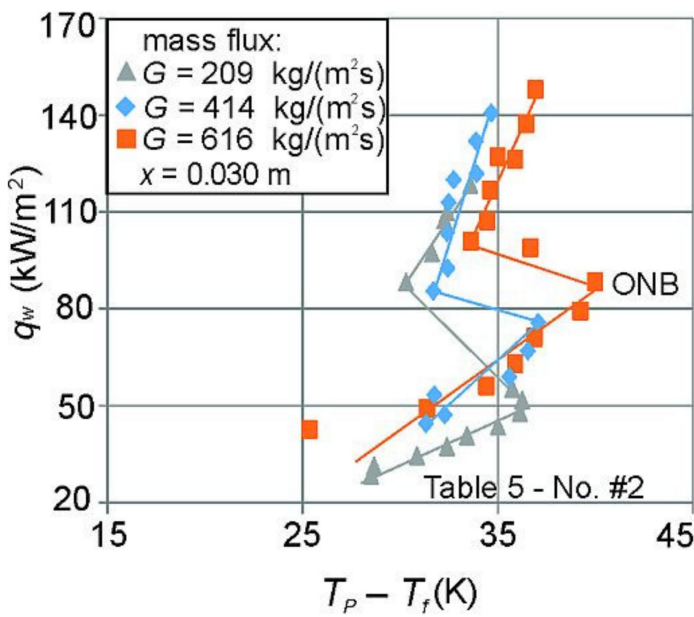

(a)

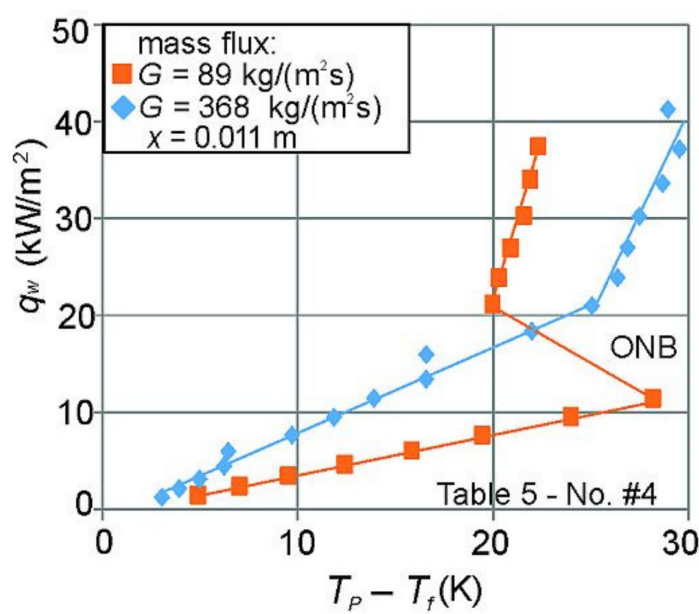

(c)

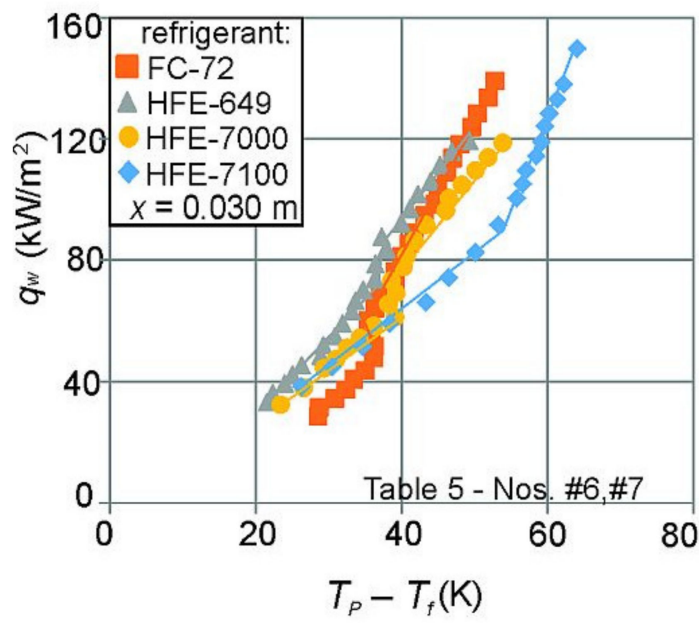

(e)

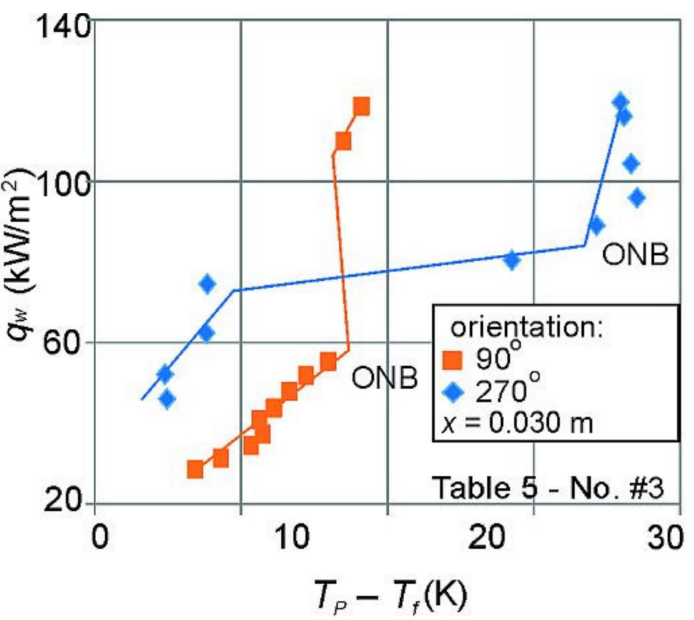

(b)

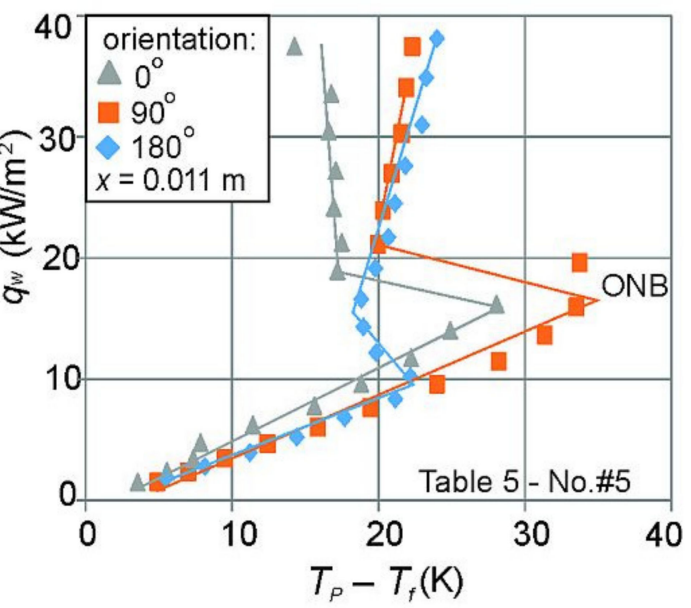

(d)

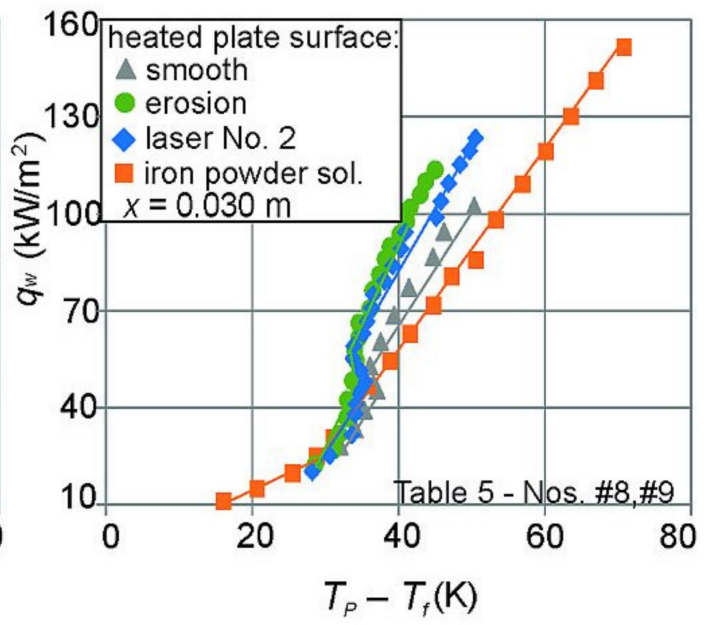

(f)

Figure 16. Boiling curves generated for two distances from the mini-channel inlet: (a,c,d) $0.030 \mathrm{~m}\left(L_{I R T}=180 \mathrm{~mm}\right)$, (b) $0.011 \mathrm{~m}\left(L_{I R T}=32 \mathrm{~mm}\right)$. Experimental parameters are shown in Table 5, Nos. \#2 to \#9. ONB - onset of nucleate boiling. 
Boiling curves show the relationship between heat flux, qw, and the difference in temperature, TP - Tf. They were generated at selected distances from the mini-channel inlet. The curves presented on one graph were constructed for: various mass fluxes (Figure 16a,c), two vertical orientations of the mini-channel (Figure 16b), two horizontal orientations of the mini-channel and vertical mini-channel with fluid up-flow (Figure 16d), four refrigerants (Figure 16e) and mini-channels with smooth and modified heated plate surfaces (Figure 16f). It is known that at the subcooled boiling region, an increase in heat flux may cause a sudden decrease in the heated-wall temperature during the incipience of boiling and detachment of the first bubbles. This phenomena is known as "nucleation hysteresis". Points marked as 'ONB' (onset of nucleate boiling) on the boiling curves' courses were selected due to the highest difference in temperature, TP - Tf. When analyzing the boiling curves presented in Figure 16i, it can be pointed out that:

- With the increase of mass flux, the temperature difference corresponding to ONB increased-see Figure 16a,c.

- The temperature difference at $\mathrm{ONB}$ was higher for $\mathrm{O}-270^{\circ}$ in comparison to $\mathrm{O}-90^{\circ}$, see Figure 16b.

- The highest temperature difference at ONB was observed for the vertical channel with fluid up-flow $\left(O-90^{\circ}\right)$, in comparison to both horizontal orientations $\left(O-0^{\circ}\right.$ and $\left.O-180^{\circ}\right)$-see Figure $16 \mathrm{~d}$.

- The highest temperature difference at ONB occurred for HFE 7100 in comparison to other tested fluids-see Figure 16e.

- The lowest temperature difference at ONB was gained for electroerosion and vibrationassisted laser No. 2 surface texturing, and the highest one for porous surfaces produced by soldering iron powder-see Figure $16 \mathrm{f}$.

\section{Conclusions}

This work presented the results of boiling heat transfer during flow in rectangular mini-channels. The influence of selected factors on heat transfer were discussed, i.e., main experimental parameters (inlet pressure and mass flux), mini-channel dimensions and spatial orientation, using modified heated plate surfaces. Four refrigerants (FC-72, HFE-649, HFE-7000, HFE-7100) were applied as the working fluid. The test sections with a single rectangular mini-channel (180 $\mathrm{mm}$ long) or with a group of five parallel mini-channels (each $32 \mathrm{~mm}$ long) were used during experiments performed at stationary condition.

The results were presented as local heated-wall temperatures and heat transfer coefficients and boiling curves. Two-phase flow patterns were also illustrated and discussed.

The major remarks and conclusions can be drawn concerning the influence of selected factors on heat transfer during flow boiling in mini-channels, as follows:

- Inlet pressure (subcooled boiling region):

- Higher HPT was achieved at higher $p_{\text {in }}$, and higher HTC at lower $p_{\text {in }}(180 \mathrm{~mm}$ long channel).

- Mass flux (subcooled boiling region):

- Higher HPT was reached for lower $G$ (both test sections), the highest HTC was obtained for the lowest $G$ at the highest $q_{w}$ ( $180 \mathrm{~mm}$ long channel), and for the higher $G$ at lower $q_{w}$ (32 $\mathrm{mm}$ long channel), and larger bubbles were observed near channel side walls for the lowest $G$.

- Spatial orientation of a mini-channel (subcooled boiling region):

- The highest HPT was noticed for the lowest $G$ and at $O-270^{\circ}$, for lower $q_{w}$. The highest HTC was achieved for higher $G$ and all $q_{w}$, for $O-270^{\circ}$, and more gaseous phase with locally elongated agglomerates was observed for $\mathrm{O}-270^{\circ}$ (180 mm long channel).

- The highest HPT was detected for all $q_{w}$, the highest HTC was obtained for the highest $q_{w}$ and the lowest and the least fragmented bubbles (32 $\mathrm{mm}$ long channel) for $\mathrm{O}-0^{\circ}$. 
- Working fluids:

- The highest HTC was achieved for HFE-7000 for all $q_{w}$, at the subcooled boiling region, and for FC-72 and HFE-7000, for all $q_{w}$, at the saturated boiling region. More developed vapor structures as elongated agglomerates were observed for FC-72 in comparison to other refrigerants, and for HFE-7000, bubbly, bubblyslug and slug structures were recorded.

- Heated plate surface of a mini-channel:

$\circ \quad$ The highest HTC was obtained for electroerosion and vibration-assisted laser No. 2 surface texturing at both boiling regions. The highest vapor share in two-phase flow structures with elongated agglomerates in comparison to other tested plate surfaces was observed for electroerosion surface texturing, and bubbles of larger sizes and elongated agglomerates were recorded for vibration-assisted laser No. 2 surface texturing.

When analyzing boiling curves, it was observed that with the increase of mass flux, the temperature difference corresponding to ONB increased, the temperature difference at ONB was higher for $O-270^{\circ}$ in comparison to $O-90^{\circ}$, the highest temperature difference at ONB was observed for vertical channel orientation with fluid up-flow $\left(\mathrm{O}-90^{\circ}\right)$, the highest temperature difference at ONB was detected for HFE 7100 in comparison to other tested fluids and the lowest temperature differences at ONB were gained for electroerosion and vibration-assisted laser No. 2 surface texturing, and the highest for porous surfaces produced by soldering iron powder.

Author Contributions: Conceptualization, methodology, M.P. and K.S.; investigations, calculations, visualization, K.S.; validation, formal analysis, writing-original draft preparation, review and editing, M.P. and K.S.; funding acquisition, M.P. All authors have read and agreed to the published version of the manuscript.

Funding: This research was funded by the National Science Centre, Poland, grant number UMO2018/31/B/ST8/01199.

Data Availability Statement: Data sharing not applicable.

Acknowledgments: The research reported herein was supported by a grant from the National Science Centre, Poland, No. UMO-2018/31/B/ST8/01199.

Conflicts of Interest: The authors declare no conflict of interest.

\section{Nomenclature}

A area of the heated plate, $\mathrm{m}^{2}$

$f \quad$ fluid

G mass flux, $\mathrm{kg} /\left(\mathrm{m}^{2} \cdot \mathrm{s}\right)$

HPT heated plate temperature, $\mathrm{K}$

HTC heat transfer coefficient, $\mathrm{W} /\left(\mathrm{m}^{2} \cdot \mathrm{K}\right)$

I current, A

$L \quad$ length of the mini-channel, $\mathrm{m}$

$\mathrm{O} \quad$ channel orientation

ONB onset of nucleate boiling

$p_{\text {in }} \quad$ pressure at the mini-channel inlet, $\mathrm{Pa}$

$q_{w} \quad$ heat flux density, $\mathrm{W} / \mathrm{m}^{2}$

$\mathrm{Ra} \quad$ arithmetic mean deviation of the roughness profile of the plate surface, $\mu \mathrm{m}$

$S \quad$ heated plate surface

$T \quad$ temperature, $\mathrm{K}$

the 1st the test section with a singular mini-channel of $L_{I R T}=180 \mathrm{~mm}$

the 2nd the test section with five parallel mini-channels of $L_{I R T}=32 \mathrm{~mm}$

$x \quad$ direction perpendicular to the fluid flow direction and the channel width, $\mathrm{m}$ 


$\begin{array}{ll}\begin{array}{ll}\text { Greek symbols } \\ \delta\end{array} & \begin{array}{l}\text { depth, thickness, } \mathrm{m} \\ \Delta U \\ \lambda\end{array} \\ \text { voltage drop, } \mathrm{V} \\ \text { Subscripts } & \text { thermal conductivity, } \mathrm{W} /(\mathrm{m} \cdot \mathrm{K}) \\ f & \text { fluid } \\ I R T & \text { infrared thermography } \\ l & \text { liquid } \\ P & \text { plate } \\ \text { sat } & \text { saturated }\end{array}$

\section{References}

1. Kanizawa, F.T.; Tibiriçá, C.B.; Ribatski, G. Heat transfer during convective boiling inside microchannels. Int. J. Heat Mass Transf. 2016, 93, 566-583. [CrossRef]

2. Sun, Z.-C.; Ma, X.; Ma, L.-X.; Li, W.; Kukulka, D. Flow Boiling Heat Transfer Characteristics in Horizontal, Three-Dimensional Enhanced Tubes. Energies 2019, 12, 927. [CrossRef]

3. Jige, D.; Inoue, N. Boiling heat transfer, pressure drop, and flow pattern in a horizontal square minichannel. Int. J. Heat Fluid Flow 2019, 78, 108433. [CrossRef]

4. See, Y.S.; Leong, K.C. Entropy generation for flow boiling on a single semi-circular minichannel. Int. J. Heat Mass Transf. 2020, 154, 119689. [CrossRef]

5. He, B.; Luo, X.; Yu, F.; Zhou, J.; Zhang, J. Flow boiling characteristics in bi-porous minichannel heat sink sintered with copper woven tape. Int. J. Heat Mass Transf. 2020, 158, 119988. [CrossRef]

6. Klugmann, M.; Dąbrowski, P.; Mikielewicz, D. Flow distribution and heat transfer in minigap and minichannel heat exchangers during flow boiling. Appl. Therm. Eng. 2020, 181, 116034. [CrossRef]

7. Cheng, X.; Yao, Y.; Wu, H. An experimental investigation of flow boiling characteristics in silicon-based groove-wall microchannels with different structural parameters. Int. J. Heat Mass Transf. 2021, 168, 120843. [CrossRef]

8. Enoki, K.; Ono, M.; Okawa, T.; Kristiawan, B.; Wijayanta, A.T. Water flow boiling heat transfer in vertical minichannel. Exp. Therm. Fluid Sci. 2020, 117, 110147. [CrossRef]

9. Markal, B.; Candan, A.; Aydin, O.; Avci, M. Experimental investigation of flow boiling in single minichannels with low mass velocities. Int. Commun. Heat Mass Transf. 2018, 98, 22-30. [CrossRef]

10. Gasanov, B.M. Flow boiling of water and emulsions with a low-boiling disperse phase in minichannels. Int. J. Heat Mass Transf. 2018, 126, 9-14. [CrossRef]

11. Orman, Ł.J.; Radek, N.; Pietraszek, J.; Szczepaniak, M. Analysis of enhanced pool boiling heat transfer on laser-textured surfaces. Energies 2020, 13, 2700. [CrossRef]

12. Dąbek, L.; Kapjor, A.; Orman, Ł.J. Distilled water and ethyl alcohol boiling heat transfer on selected meshed surfaces. Mech. Ind. 2019, 20, 701. [CrossRef]

13. Wojtasik, K.; Rullière, R.; Krolicki, Z.; Zajaczkowski, B.; Bonjour, J. Subcooled boiling regime map for water at low saturation temperature and subatmospheric pressure. Exp. Therm. Fluid Sci. 2020, 118, 110150. [CrossRef]

14. Hożejowska, S.; Kaniowski, R.; Pastuszko, R. Application of the Trefftz Method for Pool Boiling Heat Transfer on Open Microchannel Surfaces. Heat Transf. Eng. 2021, 1-13. [CrossRef]

15. Pastuszko, R.; Kaniowski, R.; Wójcik, T.M. Comparison of pool boiling performance for plain micro-fins and micro-fins with a porous layer. Appl. Therm. Eng. 2020, 166, 114658. [CrossRef]

16. Kaniowski, R.; Pastuszko, R. Pool Boiling of Water on Surfaces with Open Microchannels. Energies 2021, 14, 3062. [CrossRef]

17. Bohdal, T.; Kruzel, M. Refrigerant condensation in vertical pipe minichannels under various heat flux density level. Int. J. Heat Mass Transf. 2020, 146, 118849. [CrossRef]

18. Kruzel, M.; Bohdal, T.; Sikora, M. Heat transfer and pressure drop during refrigerants condensation in compact heat exchangers. Int. J. Heat Mass Transf. 2020, 161, 120283. [CrossRef]

19. Strak, K.; Piasecka, M.; Maciejewska, B. Spatial orientation as a factor in flow boiling heat transfer of cooling liquids in enhanced surface minichannels. Int. J. Heat Mass Transf. 2018, 117, 375-387. [CrossRef]

20. Strak, K.; Piasecka, M. The applicability of heat transfer correlations to flows in minichannels and new correlation for subcooled flow boiling. Int. J. Heat Mass Transf. 2020, 158, 119933. [CrossRef]

21. Piasecka, M.; Strąk, K.; Maciejewska, B. Heat transfer characteristics during flow along horizontal and vertical minichannels. Int. J. Multiph. Flow 2021, 137, 103559. [CrossRef]

22. Piasecka, M.; Strak, K. Influence of the Surface Enhancement on the Flow Boiling Heat Transfer in a Minichannel. Heat Transf. Eng. 2019, 40, 1162-1175. [CrossRef]

23. Depczyński, W.; Piasecki, A.; Piasecka, M.; Strak, K. Impact of Fe powder sintering and soldering in production of porous heating surface on flow boiling heat transfer in minichannels. E3S Web Conf. 2017, 19, 03012. [CrossRef]

24. Maciag, A.; Grysa, K. Trefftz Method of Solving a 1D Coupled Thermoelasticity Problem for One- and Two-Layered Media. Energies 2021, 14, 3637. [CrossRef] 
25. Blasiak, S. Influence of Thermoelastic Phenomena on the Energy Conservation in Non-Contacting Face Seals. Energies 2020, 13, 5283. [CrossRef]

26. Piasecka, M.; Maciejewska, B.; Łabędzki, P. Heat Transfer Coefficient Determination during FC-72 Flow in a Minichannel Heat Sink Using the Trefftz Functions and ADINA Software. Energies 2020, 13, 6647. [CrossRef]

27. Piasecka, M.; Hożejowska, S.; Maciejewska, B.; Pawińska, A. Time-Dependent Heat Transfer Calculations with Trefftz and Picard Methods for Flow Boiling in a Mini-Channel Heat Sink. Energies 2021, 14, 1832. [CrossRef]

28. Michalski, D.; Strak, K.; Piasecka, M. Estimating uncertainty of temperature measurements for studies of flow boiling heat transfer in minichannels. EPJ Web Conf. 2019, 213, 02059. [CrossRef]

29. Maciejewska, B.; Łabędzki, P.; Piasecki, A.; Piasecka, M. Comparison of FEM calculated heat transfer coefficient in a minichannel using two approaches: Trefftz base functions and ADINA software. EPJ Web Conf. 2017, 143, 02070. [CrossRef]

30. Piasecka, M.; Strak, K.; Maciejewska, B. Calculations of Flow Boiling Heat Transfer in a Minichannel Based on Liquid Crystal and Infrared Thermography Data. Heat Transf. Eng. 2017, 38, 332-346. [CrossRef]

31. Strak, K.; Piasecka, M. Research on flow boiling heat transfer for vertical upward and downward flows along a minichannel with a smooth heated surface. E3S Web Conf. 2018, 70, 02014. [CrossRef]

32. Strąk, K.; Piasecka, M.; Strak, D. Enhanced Surfaces Used in Research on Flow Boiling Heat Transfer in Minichannels. Mater. Res. Proc. 2018, 5, 154-159. 